\title{
1. Law, legal scholarship and the conservation of biological diversity: 2020 vision and beyond
}

\section{Michael Bowman}

\section{INTRODUCTION}

It can hardly be doubted that the current state of the world's biological diversity provides cause for the gravest possible concern. As was candidly conceded by a wide-ranging survey prepared by the Convention on Biological Diversity (CBD) Secretariat for the purposes of the International Year which the UN had originally dedicated to the topic: ${ }^{1}$

The target agreed by the world's Governments in 2002, 'to achieve by 2010 a significant reduction of the current rate of biodiversity loss at the global, regional and national level as a contribution to poverty alleviation and to the benefit of all life on Earth', has not been met.

The evidence of this failure was all around. Many of those species whose prospects of survival had been formally assessed were moving closer to extinction, with coral species experiencing the most rapid rate of deterioration and amphibians facing the greatest risk generally. Nearly a quarter of all plant species were judged to be threatened with extinction, while population surveys suggested that the overall abundance of vertebrate species had fallen by nearly one-third between 1970 and 2006, and was still falling, with the severest declines occurring in the tropics and amongst freshwater species. Despite some successes in slowing the process, natural habitats generally continued to decline in both extent and integrity. The services provided by forests, rivers and other natural ecosystems had progressively been compromised by fragmentation and degradation, while the genetic diversity of crops and livestock in agricultural systems remained in decline. The five principal drivers of biodiversity loss - habitat change, overexploitation, pollution, invasive alien species and climate change - were either undiminished or actually increasing in intensity. In sum, humanity's ecological footprint exceeded the biological capacity of the earth by an even wider margin than at the time the 2010 target was originally agreed. ${ }^{2}$ This failure was acknowledged by the decision of the UN to follow the International Year of Biodiversity with the devotion of an entire decade to the global conservation project, ${ }^{3}$

CBD Secretariat, Global Biodiversity Outlook 3 (2010), Executive Summary, 9.

2 Ibid.

3 UNGA Resolution 65/161, specifying 2011-2020 for this purpose, in accordance with the current strategic plan of the 1992 Convention on Biological Diversity (CBD), (1992) 31 ILM 818. 


\section{Research handbook on biodiversity and law}

in the hope of achieving significant progress, if not actually turning things around, by the year 2020.

We are now effectively half way through the decade in question, and there are still disturbingly few signs of the progress required. The latest major survey prepared by WWF, which announces itself to be 'not for the faint-hearted' ${ }^{4}$ suggests that since 1970 (i.e., in less than two human generations) populations of vertebrate species globally have actually dropped by just over half. ${ }^{5}$ Nevertheless, it retains a degree of confidence that we can 'close this destructive chapter in our history, and build a future where people can live and prosper in harmony with nature'. ${ }^{6}$ The CBD's own most recent appraisal paints a broadly similar picture of the current state of biodiversity conservation as decidedly troubling, but not yet irredeemable. ${ }^{7}$

It is certainly not easy to be optimistic about the prospects for securing the transformation needed, however, since all these unmistakeable indicators of deterioration have become apparent during the very period in which we have also experienced an exponential increase in our knowledge and understanding of the centrality of biodiversity conservation to the preservation of the planet's life support systems, and hence of our ultimate absolute dependence upon the efforts that we make in that regard ${ }^{8}$ Thus, although we cannot, on any objectively plausible basis, any longer claim ignorance of either the nature or importance of the task, or of the most viable approaches to its performance, it would seem that the foibles of human nature are such that in practice we continue to experience the greatest of difficulty in bringing ourselves to address these issues effectively or even, in some quarters, to acknowledge their existence or seriousness at all. All endeavours to procure a committed and systematically rational response from humankind to challenges such as these have much in common with attempts to herd cats or to scoop up milk in the fingers: only a very small proportion of the total target, at best, seems likely to be secured.

This sorry saga of progressive ecological impoverishment certainly cannot, however, be attributed to any lack of formal legal regulation of the problem, since it has now been the subject of transnational regulatory attention, if only in extremely piecemeal fashion initially, for the best part of 150 years, and over the last few decades in particular an elaborate network of multilateral treaty regimes has been assembled to address the symptoms on a much more systematic basis. Over the course of that latter period, moreover, a significant body of legal scholarship devoted to the explication and analysis of the regimes in question has finally begun to emerge. ${ }^{9}$ These developments,

4 See <http://www.wwf.eu/media_centre/publications/living_planet_report/>. The report itself (WWF, Living Planet Report 2014) is downloadable from this site.

5 The Index 'measures more than 10,000 representative populations of mammals, birds, reptiles, amphibians and fish'.

6 See the WWF website (n 4).

7 CBD Secretariat, Global Biodiversity Outlook 4 (2014).

8 In addition to the publications mentioned above, see also the 1980 World Conservation Strategy, devised by IUCN in collaboration with other interested organisations, and its 1991 revision, Caring for the Earth.

9 The Journal of International Wildlife Law and Policy, published first by Kluwer International (1998-2002) and then by Taylor \& Francis/Routledge has undoubtedly played a significant part in this process. 
it might have been supposed, were very definitely to be regarded as entries on the credit side of the balance sheet on which the global conservation account is recorded, but there are those, it would seem, whose enthusiasm for them is decidedly muted. After all, if this substantial body of law has actually failed to counter the damaging trends towards biodiversity impoverishment which are mentioned above, then there must surely be grounds for questioning its efficacy.

Thus, in a recent review essay prompted by the publication of a new edition of Lyster's International Wildlife Law (hereafter Lyster), ${ }^{10}$ of which the present writer was a co-author, the California-based political scientist Geoffrey Wandesforde-Smith expressed the view that the world had lost its appetite for 'making big splashes' with new treaty regimes, and might currently even be more interested in conducting its international conservation endeavours 'around, rather than through' those that already exist. ${ }^{11}$ Accordingly, while he was fleetingly fulsome in his praise for the breadth, depth and quality of the analysis of the global conservation measures which the book contained, ${ }^{12}$ his clear message was that this alone was not enough, and that the omission to address certain 'broader questions' - such as the demand by environmentally committed readers to know what they should do next in order to make a positive impact in this field - must be seen to reflect the lack of a strong and clear inspirational vision in the work as a whole.

\section{THE VEXED QUESTION OF VISION}

In the ordinary way, there is probably little to be gained from authors responding directly to reviews of their work, but in this particular case there are grounds for interpreting the essay as a calculated attempt to initiate a dialogue regarding the shape and direction that legal scholarship concerning biodiversity conservation should most profitably assume in the future. ${ }^{13}$ This is a project that might justly be regarded as important both from the perspective of its contribution to legal education and research, and in the light of its potential practical impact upon the conservation process itself. Such questions are moreover, especially pertinent to such a work as the present, given that these are the very issues that it seeks to explore and illuminate. In these circumstances, the challenge is not an easy one to ignore, notwithstanding the fact that the gauntlet has been thrown down in terms that are likely to generate certain misgivings.

10 MJ Bowman, PGG Davies and CJ Redgwell, Lyster's International Wildlife Law (2nd edn., CUP, 2010). The original volume was, of course, S Lyster, International Wildlife Law (Grotius, 1985).

${ }^{11}$ G Wandesforde-Smith, 'From Sleeping Treaties to the Giddy Insomnia of Global Governance: How International Wildlife Law Makes Headway' (2012) 15 JIWLP 80, 93. It is noticeable, however, that no real evidence is presented in support of this contention.

12 Ibid., 80, 90, 93-94.

13 Thus, Professor Wandesforde-Smith not merely secured the publication of his review in the excellent journal of which he is currently associate editor, but took the additional step of sending copies to each of the authors of the new Lyster personally, as well as to its publishers, Cambridge University Press. 


\section{Research handbook on biodiversity and law}

In particular, accusations of 'lack of vision' are nowadays all too likely to be interpreted merely as forlorn lamentations that others cannot be relied upon to share the speaker's own singular, and very possibly idiosyncratic, perspective upon the world. ${ }^{14}$ A good part of the reason for that is doubtless that the word 'vision' itself became so devalued through systematic overuse in the self-serving rhetoric of political spin doctors and corporate PR operatives during that most wasteful, and wasted, of decades, the 1980s, that it is now less likely to serve as a source of inspiration than to provoke sighs of weary resignation or even cries of outright derision. ${ }^{15}$ Yet, given the undoubted seriousness of the issues to which the reviewer's observations relate, it would surely be unforgiveable simply to give in to cynicism of this kind and thereby allow potentially important insights on his part to be marginalised or disregarded merely on account of the language in which his critique was couched. After all, the success of any political project would seem to require some reasonably clear sense of what it is trying to achieve and how it is going to achieve it, and in ostensible recognition of that point the institutional organs of the biodiversity treaties themselves continue to invoke the notion of 'vision' in their own policy pronouncements and planning arrangements. ${ }^{16}$

At the same time, if his observations are to be given due weight, it will be helpful as a preliminary to pay closer attention to what we might reasonably mean when deploying the terminology of 'vision'. It is, after all, an extremely wide-ranging and multi-faceted expression, applied with equal alacrity in everyday usage to both the process and the product of visual discernment, and in literal and metaphorical fashion alike: in this way it has come to embrace everything from general cognitive photosensitivity to sheer hallucination, ${ }^{17}$ incorporating along the way such notions as dreams for the future, conceptual blueprints, mission statements, and general far-sightedness or perspicacity. By way of application of the last of these senses, the expression 'men of vision' is commonly deployed (in somewhat sexist fashion, no doubt) to denote those who display extreme or unusual perspicuity in some particular respect, rather than those with merely average or commonplace capacities, or - as a simple, strictly literal interpretation would surely require - all those who are not actually blind.

It is through such curious but commonplace linguistic processes that the word has come to be associated with the bestowal of an accolade, and the ensuing scramble to

14 In this vein, note the recent assertion by the Turkish President that the principal obstacle to Turkey's full membership of the EU was not, in reality, any fault or shortcoming exhibited by Turkey itself but rather 'the EU's lack of vision', reported in Anon, 'Gül Accuses EU of Lacking Strategic Vision vis-à-vis Turkey’ Today's Zaman (Istanbul, 27 September 2010), available at $<\mathrm{http}: / /$ www.todayszaman.com/>.

15 See further on this point RE Ellsworth, Leading with Purpose: The New Corporate Realities (Stanford UP, 2002), 96-97: 'Unfortunately, ... in recent years "vision" has taken the form of a management fad, and the term has become so widely used as to lose the essence of its meaning. Derisively, it has degenerated into "the vision thing".

16 GBO-4 (n 7), for example, speaks in terms of a 'vision' for biodiversity for the year 2050.

17 As to the latter, see, for example, K Williams, 'My Psychedelic, Psychotic, Psychic and Spiritual Visions' (2014), available at <http://www.near-death.com/resources/editorials/mypsychedelic-psychotic-psychic-and-spiritual-visions.html>, especially Part 3. 
claim 'visionary' status has undoubtedly proved a further impediment to the achievement of clarity in usage. As one commentator has put it, with regard to the corporate context: ${ }^{18}$

For many CEOs, having a vision is a prerequisite to being considered an enlightened, modern leader. Consequently, vision statements have blossomed. Company after company has drafted statements to hang on walls and to place in public relations materials disseminated to employees, shareholders and the public. The terms vision, purpose, mission, shared values and strategy are often used indiscriminately and even interchangeably.

In an attempt to rescue the concept from this morass of misapplication, he continues:

But what is vision? Vision is not something separate from purpose, mission, strategy, and shared values. It is the quality that is ingrained in each of these that defines a desired future state of the organization resulting from the fulfilment of the purposes and the strategy to get there. As John Young, Hewlett-Packard's former CEO, observes, 'Vision is simply mission and purpose made tangible in people's minds.' It 'refers to a vivid description of what it will be like when the mission is accomplished or the purpose fulfilled.' Vision combines an unusual discernment of the competitive future with foresight and wisdom as to how the company can make a valued social contribution in tomorrow's marketplace. This discernment and foresight are woven into the substance of the company's purpose, mission, strategy and values and are not separate from these concepts.

While this arguably represents a small step forward in terms of clarification, it still seems to leave a good deal to be desired, first of all because it risks overstating the specificity with which it is possible to make assessments about the needs and realities of 'tomorrow', ${ }^{19}$ let alone all those days which are (hopefully at least) to follow. In addition, the 'marketplace' is hardly a forum where any meaningful evaluation of future reality can be guaranteed to occur. ${ }^{20}$ Typically, a fundamental impediment to the development of a feasible and compelling agenda for the future is the failure to establish a sufficiently clear and accurate picture of the starting point for the process that is, of the current condition and functional operations of the enterprise in question, in all their complexity. Ideally, moreover, this picture would be informed by a reasonably clear sense of how all these realities came about in historical terms. Indeed, until such a detailed and authentic appreciation of the status quo has been constructed, strategic planning for the future seems likely to prove largely futile.

Where the preservation of biological diversity is concerned, one key aspect of the planning problem is that it may in some cases take only days or months, but in others possibly years or even decades, ${ }^{21}$ before the full impacts of conservation measures become discernible on the ground, rendering it extremely difficult for the complex

18 Ellsworth (n 15).

19 On the significance of unpredictability for decision making generally, see J Kay, Obliquity: Why Our Goals Are Best Achieved Indirectly (Profile Books, 2010).

20 This is because within the traditional economic perspective future contingencies are heavily discounted: see A Gillespie, International Environmental Law Policy and Ethics (2nd edn., OUP, 2014), chapter 3.

21 More realistically, some complex combination of the above interludes is likely to be involved. 


\section{Research handbook on biodiversity and law}

relationships of cause and effect to be successfully unravelled. A currently deteriorating position in the vigour or abundance of protected wildlife might as easily be the result of imprudent policies that were implemented in the past (and perhaps even in a previous century) as of those that are presently in effect, rendering it extremely unwise to treat declining populations per se as a justification for launching into some dramatic programme of normative reform. ${ }^{22} \mathrm{~A}$ further factor is that even if the substantive thrust of conservation law and policy is well judged, it may take a very long while before effective approaches to implementation and enforcement are fully operative, especially when the key mechanism to be employed is that of the criminal law. ${ }^{23}$ All too often, the lack of due seriousness with which such matters are treated means that offenders are encouraged to believe that they may flout the law with relative impunity.

It is only very recently that indications have become apparent that the international community is finally beginning to wake up to the full seriousness of the problems involved. ${ }^{24} \mathrm{~A}$ further element of the difficulties to be faced here is that the majority of the principal threats to biodiversity are actually attributable to factors and policies which originate entirely from outside what is typically regarded as the conservation sector, reinforcing the idea that the solution may lie not in the reconstruction or abandonment of existing conservation regimes but in the more effective integration and consolidation of their message across the governmental machine as a whole.

\subsection{Vision, Visionaries and the Risks of Revisionism}

Needless to say, it would make even less sense to contemplate some very drastic upheaval in existing conservation regimes where the weaknesses that had been attributed to them were actually the result of mere misunderstanding of their true substantive purport, past evolutionary development or current modes of operation. The point cannot be over-emphasised within the context of international wildlife law because, whereas there seems actually to be no shortage of extravagant and confidently expressed proposals of a strategic character, a striking deficiency has always been apparent with regard to the establishment of anything resembling a complete, cogent and coherent picture of the current state of affairs and operations, and of precisely what

22 See, for example, D Tilman, and others, 'Habitat Destruction and the Extinction Debt' (1994) 371 Nature 65; A Helm, I Hanski and M Partel, 'Slow Response of Plant Species Richness to Habitat Loss and Fragmentation' (2006) 9 Ecology Letters 72; M Kuussaari and others, 'Extinction Debt: A Challenge for Biodiversity Conservation' (2009) 24 Trends in Ecology \& Evolution 564; A Sang and others, 'Indirect Evidence for an Extinction Debt of Grassland Butterflies Half Century after Habitat Loss’ (2010) 143 Biological Conservation 1405.

23 For reports of an interesting array of promising recent developments in the prosecution of wildlife offences in the UK, see the RSPB's investigations newsletter, Legal Eagle, Issue No 75, March 2015.

24 The declaration of the UN Decade for Biodiversity is one, along with the creation in 2012 of IPBES (the Intergovernmental Platform on Biodiversity and Ecosystem Services), the initiation of the UN's Harmony with Nature project (see n 103 below) and the recent recognition of wildlife crime as a threat both to sustainable development and to international peace and security, as to which see E McLellan and others, Illicit Wildlife Trafficking: An Environmental, Economic and Social Issue (Perspectives, Issue No.14, UNEP, May 2014). 
the law is, and how it came to be so. Thus, a number of the earlier evaluations of the Ramsar Convention were gravely undermined by their failure to examine with sufficient precision or rigour the way in which the regime was actually operating and evolving in practice. ${ }^{25}$

To take another example, when evaluating the proposition that the wildlife trade Convention, CITES, ${ }^{26}$ would operate much more efficiently and effectively if its basic procedures were turned on their head, in the sense that the listing process should be reconceived so as to specify those species in which trade was permitted, ${ }^{27}$ it helps at least to be aware that just such a proposal was specifically examined and rejected as unworkable in the Convention's early years. ${ }^{28}$ Otherwise, one might simply end up reinventing the wheel, and very possibly a square wheel at that! Similarly, when it is repeatedly asserted by certain cadres of commentator that the very adoption of a Convention regulating the global wildlife trade was born largely of a failure to appreciate the importance of habitat loss as the critical overall threat to wildlife species, ${ }^{29}$ it becomes important to understand that the historical record lends no support whatsoever to this contention. ${ }^{30}$ Rather, it seems that uncritical enthusiasm in certain quarters for trade as a vehicle of human development has given rise to the promulgation of a largely imagined historical narrative to support the ideological predispositions of its authors. ${ }^{31}$ As a final illustration, it has been relatively rare to encounter appraisals of the 1946 Whaling Convention that go beyond the recitation of trite, and largely inaccurate, suppositions about its origins and objectives. ${ }^{32}$

The tendency towards glib revisionism where history is concerned is arguably no more strongly evident than in widely espoused (though generally under-evidenced) contemporary claims that the global conservation effort has traditionally been driven essentially by 'Romantic' thinking. It is troublesome enough to encounter such claims

25 See, for example, D Farrier and L Tucker, 'Wise Use of Wetlands under the Ramsar Convention: A Challenge for Meaningful Implementation of International Law' (2000) 12 JEL 21, in response to which the Ramsar Bureau took the unusual step of issuing a public rebuttal. This comprised a letter to the editor of the journal in which the article was published and an internal paper commissioned by an Australian wetlands expert exposing the misapprehensions it was believed to contain.

261973 Convention on International Trade in Endangered Species of Wild Fauna and Flora, 993 UNTS 243.

27 E Couzens, 'CITES at Forty: Never Too Late to Make Lifestyle Changes' (2013) 22 RECIEL 311.

28 See CITES Conf. 3.21; Docs. 3.30, 3.30.1; ML Ditkof, 'International Trade in Endangered Species under CITES: Direct Listing vs Reverse Listing' (1982) 15 Cornell International Law Journal 107. Couzens, ibid., acknowledges the point only in his conclusions, at 322, but suggests that circumstances have changed since then.

29 See, for example, J Hutton and B Dickson (eds.), Endangered Species, Threatened Convention: The Past, Present and Future of CITES (Earthscan, 2000), xv, 47, 129.

30 For discussion, see MJ Bowman, 'A Tale of Two CITES: Divergent Perspectives upon the Effectiveness of the Wildlife Trade Convention' (2013) 22 RECIEL 228, 233-235.

31 Ibid.

32 For an attempt to set the record straight, see MJ Bowman, "Normalizing" the International Convention for the Regulation of Whaling' (2008) 29 Michigan Journal of International Law 293. 
in writings in the literary field, ${ }^{33}$ but more disturbing by far when they appear to be advanced by those whose work might impact more directly upon the actual application and development of conservation policy. ${ }^{34}$ Romanticism was, after all, primarily a literary and artistic movement rather than one driven by philosophers ${ }^{35}$ or politicians, ${ }^{36}$ and its principal impact upon human attitudes to nature has been manifest more in the weekend musings of the leisured classes than in the workaday management of the natural landscape. The latter, in truth, has always been driven far more strongly by the cold, controlling, mechanistic and utilitarian thinking associated with the earlier age of so-called reason and enlightenment, to which Romanticism represented no more than a lively but limited backlash. ${ }^{37}$ Thus, the traditional approach to 'sustainable' forest management has convincingly been traced back to 18th-century Prussia, where it was driven not by starry-eyed engrossment with all things silvestrian but by the urgent, ongoing demand for timber for the mining industry. ${ }^{38}$ Accordingly, any glimmers of genuine holistic understanding that were revealed by the original architects of this brand of conservation policy were rather rapidly submerged in practice by more mundane and materialistic impulses, ${ }^{39}$ leading ultimately to the establishment of vast

33 Note in this vein the assertion that 'Romanticism forms the base from which Western society, especially American, views its natural surroundings': KA Mingey, New Romanticism (University of Montana Scholar Works, 2007), 2.

34 See, for example, P Kareiva, M Marvier and R Lalasz, 'Conservation in the Anthropocene: Beyond Solitude and Fragility' (2011) <http://thebreakthrough.org/index.php/journal/pastissues/issue-2/conservation-in-the-anthropocene>; K Willis and C Fry, Plants: From Roots to Riches (John Murray, 2014), especially chapter 24. The first- and third-named authors of the former work are respectively Chief Scientist and Director of Science Communications at the Nature Conservancy, an influential US pressure group which pursues a global environmental programme, while the first-named of the latter is Director of Science at the Royal Botanic Gardens at Kew, in England, which fulfils a host of important functions in connection with the UK's national and international conservation commitments.

35 Needless to say, it had its philosophical champions, amongst whom Rousseau, Goethe and (more controversially) Nietzsche would typically be numbered, though - as Richard Tarnas points out in his admirable and compendious study of Western thought - in Romanticism generally, and in Nietzsche in particular, the philosopher was effectively transformed into poet: $\mathrm{R}$ Tarnas, The Passion of the Western Mind (Pimlico, 1991), 371.

36 No doubt it had its impact on certain politicians, most notably Teddy Roosevelt in the US. It also proved influential in Germany, where aspects of Nazi ideology drew heavily upon Romantic thought: see, for example, P Viereck, Metapolitics: From Wagner and the German Romantics to Hitler (expanded edn., Transaction Publishers, 2003).

37 It has also been pointed out that over the course of time Romanticism came to embrace a powerful sense of alienation from nature: see Tarnas (n 35), 376. This was, moreover, largely attributable to the extent to which the mechanistic, enlightenment perception of the natural world had contrived to prevail.

38 The term Nachhaltigkeit (i.e., sustainable forest management) was coined by Hans von Carlowitz, whose 1713 work Sylvicultura Oeconomica became the 'bible' in this field. Its author was not actually a biologist, however, but a mining administrator desperate to maintain the supply of timber for the mines: see, for example, JB Ball, 'Global Forest Resources: History and Dynamics' in J Evans (ed.), The Forests Handbook, Volume 1: An Overview of Forest Science (Blackwell Science, 2001).

39 On the profound impact in other regions of the resulting theory and practice of forest management, see, for example, TJ Straka, 'Evolution of Sustainability in American Forest 
arboreal monocultures that were supposedly far more 'efficient' than anything nature itself could produce, but have in reality all too often proved to be the graveyards both of biological diversity and of the more traditional forms of community benefit that can be derived from nature. ${ }^{40}$ The engineers of this particular revolution, unfortunately, could only see the trees for their wood.

It would certainly present a major challenge to discern any trace of Romantic motivation behind the earliest legal measures regarding wildlife to be adopted at the international level, which were primarily concerned with conserving directly exploitable resources such as fish, fur seals and whales, protecting birds 'useful to agriculture', or countering the depredations of invasive alien species such as Phylloxera vastatrix, the aphid scourge of European vineyards. ${ }^{41}$ Can it seriously be contended that those who, in the solitary preambular recital to the (now long superseded) Whaling Convention of $1937,{ }^{42}$ declared the conservation of whale stocks to be designed solely 'to secure the prosperity of the whaling industry' were really just a bunch of old romantics at heart? To reinforce the point, it might be noted that few creatures have seemed more powerfully evocative to poets, especially during the Romantic era, than birds of prey, which were celebrated as symbols not merely of freedom, but of speed, strength, visual acuity and closeness to heaven, albeit with more than a hint of menace. ${ }^{43}$ Yet none of this aura availed them one jot in the early wildlife treaties, for the purposes of which they were typically not merely excluded from protection but positively earmarked for persecution. ${ }^{44}$ Accordingly, when the Scottish naturalist Seton Gordon produced his 1927 paean to the Aquila Days with the Golden Eagle, it was

Resource Management Planning in the Context of the American Forest Management Textbook' (2009) 1 Sustainability 838; C Lang and O Pye, 'Blinded by Science: The Invention of Scientific Forestry and Its Influence in the Mekong Region' (2000-2001) 6 Watershed 25.

40 Lang and Pye, ibid.; R Ziegler, 'Crooked Wood, Straight Timber - Kant, Development and Nature' (2010) 2 Public Reason 61.

$41 \quad$ See generally Lyster, chapter 1.

421937 International Agreement for the Regulation of Whaling, 190 LNTS 79.

43 The collection Lyrical Ballads (1798), which is generally regarded as having triggered the British Romantic movement, was inspired by the period spent by Coleridge and the Wordsworths living in Somerset, where the high heathland habitat of the Quantocks is noted for its birds of prey. Perhaps the best-known explicit allusion lies in Tennyson's short poem 'The Eagle' (1851-1854), though the albatross in Coleridge's own 'Rime of the Ancient Mariner' (1798) might be considered a marine equivalent (especially since it seems that part of the inspiration for this epic poem was an incident in which Coleridge himself witnessed the wanton killing of a hawk in the course of a voyage to Malta). More generally, references to raptors abound throughout the genre, in Keats, Hemans and others: for details, see D Wu, Romanticism: An Anthology (4th edn., Wiley-Blackwell, 2012), 339-357, 1329-1336, 1370, 1397, 1429, 1439, 1457. In North America, Longfellow is said to have glorified the 'unfettered self' with 'insistent images of birds of prey': A Kolodny, In Search of First Contact (Duke UP, 2012), 162.

44 See, for example, the 1900 Convention for the Preservation of Wild Animals, Birds and Fish in Africa, 94 BFSP 715, Article II(13) and Table V; 1902 Convention for the Protection of Birds Useful to Agriculture, 102 BFSP 969, Article 9 and Schedule II. In similar fashion, the 1916 and 1936 bilateral migratory bird species treaties concluded by US with Canada (originally GB), 39 Stat 1702; USTS 628, and Mexico, 178 LNTS 309, respectively did not include any birds of prey in their lists of protected species, though some were added to the latter by virtue of the 1972 amendments, 23 UST 260, TIAS 7302. 


\section{Research handbook on biodiversity and law}

considered 'a brave book to write', on account of 'the Victorian ethos that every bird with a hooked bill should be destroyed' ${ }^{45}$

It would, of course, be foolish to deny the impact that Romanticism has exerted on the development of environmental ethics, especially in North America, or that the Romantic ideal of communion with wild nature has on occasion been translated into statutory language - thus, the Act establishing Yellowstone National Park declared it to be 'dedicated and set apart as a public park or pleasuring ground for the benefit and enjoyment of the people' and provided for the strict control of exploitation of natural resources and the removal of anyone who attempted to settle there. ${ }^{46}$ Yet even the 80 million acres managed by the National Park Service represents only a tiny fragment of the total land area of the United States, and is in any event dwarfed by that controlled by the US Forest Service (193 million acres) and the Bureau of Land Management (248 million), both of whose mandates embrace sustainability, but whose focus is much more heavily upon resource exploitation. ${ }^{47}$ It would therefore be gravely mistaken to assume that Romanticism had been the predominant motivation for conservation generally, even in the US. Within the international legal order, moreover, references to aesthetic and recreational considerations did not make a prominent entry until the 1940s, and even then only in the Americas and as an overlay upon more narrowly utilitarian considerations. ${ }^{48}$ Such thinking was not really embraced by the international community as a whole until the adoption of the 1972 World Heritage Convention, ${ }^{49}$ though that instrument, for all its undoubted importance, can hardly be regarded as the centrepiece of the global conservation effort. ${ }^{50}$

Furthermore, it should never be forgotten that such thinking is plainly no less anthropocentric in orientation than the purely materialistic reasoning that historically preceded - and comfortably survived - it, since both are essentially self-regarding and self-serving in character. It is simply that one approach attends to the needs of the body

45 D Cobham, A Sparrowhawk's Lament: How British Birds of Prey are Faring (Princeton UP, 2014), 189.

46 Yellowstone Act, 1872 (17 Stat. 32).

47 See RW Gorte and others, Federal Land Ownership: Overview and Data (Congressional Research Report R42346, 8 February 2012).

48 See the 1940 Convention on Nature Protection and Wildlife Preservation in the Western Hemisphere, 161 UNTS 193. Amongst the various types of protected area envisaged by Article 1 were not only national parks, but 'national reserves' - i.e., 'regions established for conservation and utilization of natural resources under government control, on which protection of animal and plant life will be afforded in so far as this may be consistent with the primary purposes of such reserves'. No explicit motivation was given in Article 5, which addressed conservation outside protected areas, while Article 7 called for the protection of migratory birds 'of economic or aesthetic value', or to prevent outright extinction. For further discussion, see Lyster, chapter 8.

491972 Convention for the Protection of the World Cultural and Natural Heritage (1972) UNJYB 89; 11 ILM 1358. The convention's adoption marked the centenary of the establishment of Yellowstone. For discussion, see Lyster, chapter 14.

50 This assessment stems largely from the fact that, although its substantive scope (as defined by the concept of natural heritage) is potentially very wide, its primary focus has always been upon listed sites, which in the case of natural heritage extends to fewer than 200 globally, together with around 30 of mixed natural/cultural significance. 
and the other to those of the spirit. The key point here, indeed, is to understand just how much the Romantic perspective actually shared with its supposedly contrasting Enlightenment predecessor: ${ }^{51}$

Both tended to be 'humanist' in their high estimate of man's powers and their concern with man's perspective on the universe. Both looked to this world and nature as the setting of the human drama and the focus for human endeavour. Both were attentive to the phenomena of human consciousness and the nature of its hidden structures. Both found in classical culture a rich source of insight and values. Both were profoundly Promethean - in their rebellion against oppressive traditional structures, in their celebration of individual human genius, and in their relentless quest for human freedom, fulfillment [sic], and bold explanation of the new.

The notion that wildlife might merit protection for its own sake, entirely independently of human needs or interests, is a different matter altogether, being grounded in what has been described as nature's intrinsic (as opposed to instrumental or inherent) value. ${ }^{52}$ This notion did not make an unambiguous appearance until much later, in the Council of Europe's 1979 nature conservation convention, ${ }^{53}$ the focus of which is essentially restricted to European wildlife, ${ }^{54}$ and the World Charter for Nature three years later, ${ }^{55}$ which lacks legally binding effect. It was not, in fact, until the entry into force of the Biodiversity Convention a little over 20 years ago that the idea can be seen to have taken firm root in international law generally, and even then some eminent commentators were casting doubt upon its practical legal significance. ${ }^{56}$

Even though these doubts seem largely unjustified, it should be clear to everyone that the notion that nature has an independent, intrinsic value of its own represents merely the final, most recent strand in a complex skein of pluralistic justifications for conservation, the other components of which are much longer and more securely established. Indeed, whatever should be regarded as representing in principle the current philosophical underpinnings of global conservation measures, there are still undoubtedly some areas of human interaction with nature into which the concept of intrinsic value has yet to make any significant headway in practice: the most obvious instance concerns the realm of fisheries, and some may feel that it is unlikely to be a coincidence that it is here where the failure of conservation endeavours has been most

51 Tarnas (n 35), 366. It will be noted that in their chapter in this present work, Fosci and West do not even consider it worthwhile to distinguish the two forms of anthropocentric justification.

52 Lyster, chapter 3; Fosci and West, Chapter 2.

531979 Bern Convention on the Conservation of European Wildlife and Natural Habitats, ETS 104.

54 While this much may seem evident from the title alone, the matter is in reality a little more complicated; for an explanation, see Lyster, 323-327.

55 For the text of the instrument, together with its drafting history and commentary, see WE Burhenne and WA Irwin (eds.), The World Charter for Nature (2nd rev edn., Erich Schmidt Verlag, 1986).

56 See, for example, PW Birnie, AE Boyle and CJ Redgwell, International Law \& the Environment (3rd edn., OUP, 2009), 618. 


\section{Research handbook on biodiversity and law}

profound, prolonged and pervasive. ${ }^{57}$ Thus, any suggestion that it is the idea of 'protecting nature for its own sake' that 'has not worked',58 and that we should accordingly turn to a more anthropocentric and utilitarian perspective, must count as one of the most muddle-headed and misconceived proposals of modern times.

Indeed, far too many of the more trenchant criticisms of existing treaties and strident calls for 'reform' - and especially those which tout the merits of so-called 'economic' solutions - seem ultimately to be grounded in the desire to advance the personal emotional and ideological preoccupations of their authors rather than conservation objectives as such, and tend for that reason to overlook or misrepresent crucial aspects of the contemporary legal regime and the way in which it came to be as it is. ${ }^{59}$ While such solutions may undoubtedly have a place in the overall scheme of things, any attempt to present them as a universal panacea needs to be resisted and recognised for what it is - namely the product of a very singular perspective on human affairs, and one which has repeatedly failed to deliver the benefits it has so loudly and fervently promised. 60

These failures, of course, extend far beyond the field of conservation itself to permeate every aspect of human affairs: thus, by the turn of the millennium, economists of the dominant neo-classical school had become so intoxicated by their own insistence that deregulated, market-driven policies would make the familiar boom-and-bust cycle of the global economy a thing of the past that none of them actually foresaw the all-too-obviously impending crash of 2008, the formal prediction of which was left to the few remaining mavericks within the discipline. ${ }^{61}$ The susceptibility of the majority within this profession to becoming so easily blinded by the limitations of their own, still regrettably dismal, science ${ }^{62}$ plainly offers an important lesson regarding the nature of vision in this context, which is that where it is only of the 'tunnel' variety it will all too readily become an encouragement towards detachment from reality, the engine for

57 For recent assessments, see Lyster, chapter 5, part 6; R Barnes, 'Fisheries and Marine Biodiversity' in M Fitzmaurice, DM Ong and P Merkouris (eds.), Research Handbook on International Environmental Law (Edward Elgar Publishing, 2010); P Sands and J Peel, Principles of International Environmental Law (3rd edn., CUP, 2012), chapter 9, especially 447-448. McLellan and others (n 24), note that the scale of illegal fishing amounts to almost $20 \%$ of the total global catch, and is worth around 10 billion euros per year.

58 Kareiva and others (n 34).

59 For discussion of this problem in relation to CITES, for example, see Bowman (n 30).

60 For a helpful recent exploration of these issues, see A Wiersema, 'Uncertainty and Markets for Endangered Species under CITES' (2013) 22 RECIEL 239-250.

61 See S Keen, Debunking Economics: The Naked Emperor Dethroned (rev edn., Zed Books, 2011). For a variety of other valuable perspectives upon this sorry saga, see GA Akerlof and RJ Shiller, Animal Spirits (rev edn., Princeton UP, 2010); G Tett, Fool's Gold (Abacus, 2010); Ha-Joon Chang, 23 Things They Don't Tell You About Capitalism (Penguin, 2011); R Layard, Happiness (2nd rev edn., Penguin, 2011).

62 Chang, ibid., has recently suggested in an interview that his discipline currently has more in keeping with science fiction than with genuine science: see M Reisz, 'Believing the Unbelievable: Where Adam Smith and Agent Smith Meet', Times Higher Education (London) 26 March 2015. 
self-serving revisionism and the enemy of perspicacity of the genuine kind. ${ }^{63}$ Accordingly, it is necessary to be alert to the risk that, while the adoption of a 'vision' may help to give purpose and direction to any particular project, this must always be balanced against the countervailing risk that it may merely constitute the formal enshrinement of particular prejudices and preconceptions, and on that account an active impediment to progress of a genuine kind, perhaps even precipitating the ultimate derailment of the entire enterprise.

Seemingly the latest in this long line of 'visionary' distractions entails the declaration of a putatively new geological era, the 'Anthropocene', in which we finally force ourselves to acknowledge the 'fast, deep and long-lasting effects that humans have on the planet' and indeed that we have now become 'the dominant force of change on Earth'. We must, it seems, recognise that 'humans are not an outside force perturbing an otherwise natural system but rather an integral and interacting part of the Earth system itself'. Accordingly, we 'need to start adjusting our lifestyles to nature - and then to turn our human systems into nature'. ${ }^{64}$ Yet while there is not much of substance to quarrel with here, there is surely also decidedly little by way of novelty, since one could find an exposition of almost exactly the same set of ideas in the preamble to the Stockholm Declaration on the Human Environment, ${ }^{65}$ concluded over 40 years ago!

Perhaps this propensity towards reinvention of the rhetorical wheel should simply be taken as confirmation of a strongly cyclical tendency within human affairs generally: it might even, indeed, represent something to celebrate, if only there were evidence that this latest upsurge of visionary zeal were to have resulted in the creation of a more effective rallying cry for contemporary conservation efforts. Unfortunately, however, the evidence is rather to the contrary. Indeed, the new slogan, as even its latest champion is forced to concede, suffers from the all too obvious weakness that it has already been misinterpreted as a reaffirmation of 'our right to rule the natural world for narrow human interests', ${ }^{66}$ the very opposite of what was actually intended and what is now so clearly and urgently required. Yet surely it should not have taken much imagination to realise that any attempt to declare the onset of the 'Anthropocene' would be interpreted simply as a call for yet more anthropocentrism, especially when works published by way of advocacy of this idea are disseminated under the headline 'Time to Play God'.67

63 For the latest example of recognition by a financial system insider of the damagingly 'blinkered' nature of modern economics, see 'Sackcloth and Ashes on Threadneedle Street', an interview with Bank of England research chief Andy Haldane, New Scientist (London) 28 March 2015, 28-29.

64 C Schwägerl, 'Time to Play God', The Independent (London) 25 February 2015, heralding the impending publication of his book The Anthropocene - The Human Era and How it Shapes the Planet (Synergetic Press, 2015). For the origins of this idea, see PJ Crutzen, 'Geology of Mankind: the Anthropocene' (2002) 415 Nature 23; W Steffen, PJ Crutzen and JR McNeill, 'The Anthropocene: Are Humans Now Overwhelming the Great Forces of Nature?' (2007) 36 Ambio 614.

65 UN Doc A/CONF/48/14/REV.1.

66 Schwägerl (n 64).

67 Though it should, perhaps, be acknowledged that the author himself may possibly have had no personal involvement in the choice of this title. 
More worryingly still, these arguments display the all-too-familiar tendency to create a largely imagined historical and operational narrative to demonstrate (or inflate) the importance of the supposed new perspective. Thus, on the basis of a visit to a meeting of the CBD CoP in Nagoya, where the question of protected areas was discussed, the author of the piece in question interprets the existing global conservation regime as being based upon a desire to protect only nature which is 'pristine' and 'untouched', and believed on that account to be 'real'. Yet, however important the maintenance of nature reserves might be, he intones, this will not of itself be enough, as in the new era we will need to recognise, protect and even reconstruct nature everywhere if we are ultimately to flourish or even survive. ${ }^{68}$ It seems somehow to have escaped his attention that the CBD from the outset established as its primary objective the conservation of biological diversity generally, whether wild or domesticated, and wherever it might be found; furthermore, as the substantive provisions explicitly confirm, this must necessarily include all the areas beyond nature reserves and even involve purely man-made facilities created specifically for the purpose. ${ }^{69}$ Indeed, some 20 years before the CBD's adoption, the Ramsar Convention had introduced a system of protection for all wetland types, whether natural or man-made, and without regard to whether or not they had formally been accorded the status of a nature reserve in national law. ${ }^{70}$ Accordingly, it enshrined as its guiding mantra the principle of 'wise use', deliberately eschewing any policy that might be described as 'hands-off' ${ }^{71}$ Several decades even before that, moreover, the Western Hemisphere Convention, while calling for the establishment of a graduated network of conservation areas - from those exhibiting strict wilderness values to those seen primarily as reserves set aside for resource exploitation - had in fact sought to protect and preserve wildlife both within and beyond them. ${ }^{72}$

\subsection{Vision and Virtue in Legal Scholarship}

In the light of the recurrent tendency amongst commentators to lose touch with historical reality in the course of these 'visionary' outpourings, it is surely to be regarded as one of the key virtues of Lyster's monograph when it originally appeared in the mid-1980s that it seemed so resolute in its determination to resist all temptations towards tub- or table-thumping, ${ }^{73}$ and the drift into speculative, idiosyncratic or fanciful prescriptions for future action, to which this subject-matter so readily lends itself. Instead, the author's principal aim was to focus on providing a suitably detailed account of the workings of the international legal machinery of conservation that would simultaneously be lively, cogent and succinct, and yet at the same time scholarly, sober and restrained, and might through the exhibition of these qualities ultimately emerge as both engaging and authoritative. Through his success in capturing these virtues, he was

\footnotetext{
68 Schwägerl (n 64).

69 Note in particular Articles 8(c), (d), (e), (f), (h), (i), (j), (k), (l), 9.

70 Note in particular the implications of Articles 3 and 4.

71 The point was explicitly addressed in Lyster's own first edition, 206.

72161 UNTS 229; see especially Articles 5, 7, 8, 9.

73 It will doubtless have been of assistance in this regard that the work in question had its origins in a $\mathrm{PhD}$ thesis undertaken by the author within the Lauterpacht Centre for International Law at the University of Cambridge.
} 
able to lay the intellectual foundations for the development of a viable new jurisprudence of international nature conservation, which had been sadly lacking up to that point. There had, admittedly, previously been isolated works which addressed selected aspects of the subject, but seemingly nothing which could be regarded as having addressed the full range of its subject-matter and drawn together the various strands into a coherent whole, ${ }^{74}$ through the identification of the key legal principles, practices and procedures that permeated this fast expanding area of the law, as applied systematically in relation to each of the key modern treaties that populated the field. It was, indeed, really only from that point on that international wildlife law could lay credible claims to becoming a meaningful discipline at all, as commentators began to treat his work as a kind of intellectual base-camp for the serious and scholarly exploration of the many more specialised nooks and crannies of the subject-matter. ${ }^{75}$ It was, moreover, not merely out of deference to Lyster personally, but precisely because his basic approach was thought still to have so very much to commend it, that it was so readily embraced by the authors of the second edition. ${ }^{76}$ In that sense, therefore, the aim was very much to preserve the 'vision' of calm, coherent and conscientious analysis by which the original work was inspired.

Insofar as any attempt was made to modify this general approach in the new edition, it was only to the extent of seeking to contextualise the subject-matter a little more fully, through the insertion of entirely new sections at either end of the work. The introductory suite of chapters sought specifically to explain in greater depth and detail the historical development and philosophical underpinnings of international wildlife law, as well as its place in the wider global legal order. As to the former aspects, their critical importance to the development of a coherent picture of wildlife conservation has already been addressed in the discussion above, as indeed has the extent to which they have proved a fertile breeding ground for misapprehension and misrepresentation. As regards the latter, a key point is that many, and perhaps even the majority, of those who require to acquaint themselves with the operations of the major wildlife treaty regimes are likely to approach the subject from a position of relative unfamiliarity with the intricacies of the international legal system as such: their own background and expertise may lie, for example, in the realms of science or policy, or in the purely national dimension of conservation law. Accordingly, it was judged desirable to provide a brief overview of this broader legal backcloth, if only as a means of highlighting certain of its crucial aspects and directing readers to some of the more valuable sources of information about them. It may be, indeed, that it is not only the uninitiated who may benefit from a degree of exposure to such matters, since even those who can lay

74 Perhaps the nearest attempt was SS Hayden, The International Protection of Wildlife (Columbia UP, 1942, repr 2007), though its orientation was largely North American and its scope, given the time of its publication, inevitably limited. R Boardman, International Organization and the Conservation of Nature (Macmillan,1981) had provided valuable insight into the political and institutional aspects of the subject, while MJ Bean's The Evolution of National Wildlife Law (first published 1977; 3rd edn., Praeger, 1997) had offered a useful domestic perspective.

75 The extraordinary dearth of periodical literature available for citation in the original work, by comparison with the revised edition, is perhaps one of its most noticeable features.

76 Only time will tell, of course, if the same level of success has been achieved. 
claim to genuine expertise in this area may fall victim to perceptual shortfall on occasion. The point is particularly pertinent with regard to the review essay under discussion, for there are grounds for suggesting that the perspective of its author with regard to the existing realities of the international legal order seem a little blinkered or blurry here and there, even with regard to certain matters of a fairly fundamental kind.

\section{PERCEPTIONS OF THE GLOBAL CONSTITUTIONAL ORDER}

Any attempt to explore the workings of the international legal system must begin with the recognition that it is scarcely possible to conceive of a legal order without reference to the particular polity, or political community, to which it relates - legal norms must, after all, be created by someone, and with a view to regulation of the conduct of certain specified actors, as well as being motivated by certain needs or interests which they are intended to protect. In many cases, of course, they are designed to reconcile perceived conflicts of interest within the community in question, or to coax its members towards unified or at least harmonised approaches to significant problems. It is in that specific respect that certain of the comments made by Professor Wandesforde-Smith appear particularly problematic. Citing a passage from the original 1985 edition of International Wildlife Law, ${ }^{77}$ he asserts that it

is no longer useful ... to speak of an international community as the chief source of pressure on States to protect wildlife and to see to it that there is 'somebody in government ... doing something every working day' to make wildlife law and to make it effective. The idea of 'an international community' long ago fractured and multiplied into a profusion of international actors, the current number and variety of which far exceed anything Lyster had experienced when he put together his book.

He proposes instead that the expression be replaced by the term 'international environmental movement', which, he suggests, 'implicates a far more complex reality' ${ }^{78}$ It is, however, not at all easy to see how that could possibly be so, since it is surely more plausible to suppose that it is the entire political community within which international law is operative which represents the broader and more complex reality, of which 'the international environmental movement' (however that might be interpreted) is merely one element, functioning alongside the many other comparable movements devoted to alternative objectives, such as peace, disarmament, human rights, free trade, economic development and so on.

\subsection{Reflections on the Nature of 'Community'}

The passage in question also implies that it is somehow inconsistent with the essential nature of a 'community' for it to be 'fractured and multiplied into a profusion of actors', but it is again difficult to understand the basis for any such assumption. Assuredly, the expression 'community', like its Latin counterpart communitas, is often

\footnotetext{
77 Wandesforde-Smith (n 11), 85, citing Lyster (n 10), 181.

78 Wandesforde-Smith (n 11), 86.
} 
used to convey some notion of shared purpose, conviction or 'agreement', 79 but there can be no justification for insistence upon that interpretation exclusively, since it is best seen as only a secondary application of the word, rather than reflecting the irreducible core of its meaning. ${ }^{80}$ Indeed, the attribution to the word 'community' of a strong or reinforced sense of 'oneness' may possibly derive from the misconception that its Latin precursor represented a compound of the prepositional prefix com- (signifying 'with', or 'together') with the abstract noun unitas (unity). The true derivation of the word communitas (and hence the original thrust of the sense of sharing that it conveys) is, however, entirely different and altogether more subtle, since the word in reality represents a compound of com- with the plural noun form munia, alternatively rendered as moenia, a word conventionally deployed in the former spelling to signify public duties or functions and, in the latter, the walls or fortifications of a city. ${ }^{81}$ Oddly, these two ostensibly very different meanings may well be mere semantic variants of the same basic idea, the verb moenio or munio meaning to build, prepare or make provision. ${ }^{82}$

While it therefore cannot be excluded that it was some sense of the need for, or the emergence of, public functions which originally underpinned the concept of 'community', the idea which tends more commonly to be emphasised in classical etymological references is that of co-location or confinement within defined boundaries. ${ }^{83}$ Although the walls of a city represent a convenient paradigm here, the natural linguistic drift towards figurative usage inevitably results in the application of the same term regardless of whether the boundaries in question are actually man-made or even assume physical form at all. Accordingly, other commonly encountered English definitions include simply 'the public in general' and 'a body of persons in the same locality' ${ }^{84}$ If this group is of any size (and especially if it persists for any length of time) it seems almost inevitable that it will come to include numerous different sub-groups, factions and alignments within it.

In this vein, it is noteworthy that within the specialised lexicon of the life sciences, the term 'community' is used simply to indicate a group of wildlife populations that

79 See C Schwarz and others (eds.), Chambers English Dictionary (1988); DP Simpson (ed.), Cassell's New Latin Dictionary (5th edn., 1968). Certainly the etymologically related word 'common' tends to be applied in that way, in international law as in more general usage: thus, the legal concepts of common property, common heritage and common concern all reflect that sense of universality of interest.

80 For a singular (and seemingly extreme) view, note the assertion that 'communitas is utterly incapable of producing effects of commonality, of association and of communion': R Esposito, Communitas: The Origin and Destiny of Community (Stanford UP, 2010), 140. For a justifiably sceptical review of this work, see M Cohen, (2012) 18 Common Knowledge 377.

81 See Simpson (n 79). Also connected is munus, meaning some gift or service offered out of duty.

82 Ibid. Thus, the two versions of the word can be taken respectively to connote the literal/physical and metaphorical/normative bulwarks and buttresses on which society depends. The compound verb communio meant to surround with fortifications.

83 Ibid. It could, no doubt, be argued that, in the human case and in the long term at least, the one is a natural if not inevitable concomitant of the other.

84 Schwarz and others (n 79). 
inhabit the same area, and engage in interaction with each other. ${ }^{85}$ Since these will inevitably include both predators and prey, any presumption of unity of purpose or perspective seems implausible to say the least. Instead, an ecological community must be viewed as a variety of complex system, an 'assemblage of organisms bound into a functional whole by their mutual relationships'.86 Within this system, a kind of homeodynamic balance is preserved not by unity of purpose but by the richness and diversity of these interactions, which continuously recycle energy within the system and thereby forestall the drift into ultimate stillness, sterility and extinction of order that would otherwise represent the inevitable consequence of the operation of the second law of thermodynamics. ${ }^{87}$

That is not to suggest, of course, that the idea of community necessarily excludes the possibility of unity of purpose or perspective, since it will always remain possible, certainly in the human case, to create a physical, social or institutional enclave for the specific purpose of attracting a congregation of the like-minded, as for example in the case of a sports club, pressure group or religious retreat. It is also clear that the term has sometimes been explicitly employed in precisely that sense in international law, as in the case of the European Communities, ECOWAS or CARICOM. ${ }^{88}$ Yet history suggests that even in cases such as these the task of maintaining the proclaimed state of unified purpose, let alone building effectively upon it, will prove challenging in the extreme. Nor will the deployment of some alternative label, such as 'union', to describe the organisation in question necessarily have the effect of enhancing the sense of motivational cohesion, for all its pretentions in that direction. ${ }^{89}$ Furthermore, in what must surely be regarded as the more typical case of a political community, there will be no antecedent universal purpose at all, since the polity in question will only have come about in the first place as the result of mere historical happenstance rather than through an exercise of conscious planning on anyone's part. Undoubtedly, the chances of achieving a tolerable modus vivendi within the group as a whole are sure to be increased if all the various individuals and factions of which it is composed can somehow work their way towards achieving a shared sense of purpose and policy with regard to certain crucial questions; such concordance is, however, essentially a political aspiration of the community in question rather than a constitutional precondition.

85 An ecosystem is commonly defined to comprise this biological community, taken together with the physical environment in which it is located: see, for example, A Allaby and M Allaby, The Concise Oxford Dictionary of Earth Sciences (OUP, 1990); C Park, Oxford Dictionary of Environment and Conservation (OUP, 2008).

86 F Capra and PL Luisi, The Systems View of Life: A Unifying Vision (CUP, 2014), 67, with further elaboration at 341-351.

87 On the second law of thermodynamics, which stipulates that the entropy of a closed system progressively increases with time, see J Daintith (ed.), Oxford Dictionary of Physics (6th edn., OUP, 2009), 546-547. 'Entropy' is a measure of the unavailability for work of the energy within a system.

88 See respectively the 1973 Treaty establishing the Caribbean Community 947 UNTS 17 (later revised); 1975 Treaty of the Economic Community of West African States (1975) 14 ILM 1200 (later revised).

89 For conspicuous examples, note the constituent treaties of the European Union, OJEU C 326/13, 26.10.2012, and African Union, text available from <http://www.au.int/en/content/ constitutive-act-african-union>. 
Where reference is made, moreover, to 'the international community' in a general political sense, it is clear that we are speaking of a polity of this latter kind, since it has come into being over the course of time simply as a casual by-product of the progressive intensification, diversification and globalisation of human affairs. It is also a highly complex, multi-faceted and pluri-dimensional entity, since the jumble of interlocking constituencies of which it is composed may validly be described and defined by reference to a multitude of highly diverse criteria, including those of a geo-political, ethnic, linguistic, socio-cultural, religious, ideological, occupational, recreational or even purely functional kind. ${ }^{90}$ Whereas the multifarious activities associated with these different constituencies might once have been conducted predominantly within local or national boundaries, that has long since ceased to be the case, and the only encircling rampart or 'earthwork' by which they are now effectively contained is that represented by the planetary boundary itself. 91 That is certainly the reality in the case of the 'international environmental movement', and is no less true of the many other comparable constituencies mentioned above.

\subsection{The International Community and the Environment}

In the light of these considerations, the real challenge here, it might be suggested, is in the first instance to ensure that the voice of the environmental movement is not drowned out by the cacophony of claims that continuously emanate from these various other factions, as part of the ongoing process of competitive clamour that is played out amongst them. More ambitiously, however, and in the longer term, the aim must be to ensure that its message is actually absorbed into and effectively integrated with their own, in the sense that full and proper allowance is made for the basic principles of biodiversity conservation in the governance of operations that occur within and across the fields of economic development, international trade and finance, human rights, armed conflict and so on. In point of fact, this process is already under way, since formal recognition has long been accorded to conservation needs (if only, in some cases, in the form of lip service) in the formulation of the substantive legal norms by which these various areas of human endeavour are governed, above all through the principle of sustainable development. ${ }^{92}$ What is now required is that this allowance be

90 One notable example of a global community perceived from an exclusively functional perspective is the Universal Postal Union, founded originally in 1864 as the General Postal Union. The preamble to its current, 1964, constitution (as to which, see its website at $<\mathrm{http}: / /$ www.upu.int/>) defines the organisation as a 'union' of a 'universal' character designed solely to 'facilitate communication' through a system of 'inter-connected networks' of postal services potentially embracing all 'the inhabitants of the world'. Although this network is said to be designed with a view to 'contributing to the attainment of the noble aims of international collaboration in the cultural, social and economic fields', it would in fact persist and function even if the majority of the communications it permitted proved in practice to be fractious and divisive!

91 Certain activities, of course, such as space travel, transcend even that limitation.

92 Thus, the preamble to the 1994 Agreement establishing the World Trade Organisation, 1867 UNTS 3, reaffirms its goal of expanding trade and allowing for the optimal use of resources 'in accordance with the objective of sustainable development, seeking both to protect 
transformed into full and effective implementation and endorsement at every level and on a systematic basis.

A significant spur to this process has very recently been provided by the explicit recognition of the need to reduce biodiversity loss as a key element of the 2015 Sustainable Development Goals, ${ }^{93}$ following a much more muted reference in the Millennium Development Goals agreed by the UN in 2002. ${ }^{94}$ It would seem that, where the environment is concerned, the practical dictates of living within a community in the original sense of the word may eventually give rise to the recognition of a community of interest in the extended, Wandesfordian, sense (i.e. commonality), for the simple reason that the earth's fundamental life support systems, although robust, are not endlessly resistant to unconstrained abuse, and collective action will therefore be necessary to preserve them. Accordingly, although the "pressure on States to protect wildlife' may originally have emanated from what might be referred to as the 'international environmental movement', those particular cudgels would now seem to have been taken up, if only somewhat tentatively as yet, by the wider political community as a whole.

It is also important not to overlook the fact that this trend has been reflected in a series of highly significant individual initiatives from a wide variety of different sources. Wandesforde-Smith himself identifies 'the United States, the European Union, Canada, South Africa, Australia and New Zealand' as entities that have 'over recent decades ... for one reason or another and in some policy areas more than another in each case, shown exceptional leadership' in the conservation field. ${ }^{95}$ Yet it might be questioned whether he has been sufficiently alert here to avoid falling into the 'invidious distinctions' which he himself specifically cautions against, ${ }^{96}$ resulting in a somewhat parochial assessment. For while the entities he highlights do indeed have certain significant achievements to their name, there are some vital policy areas climate change for one - in which a number of them could as justifiably be assigned the label of laggard as that of leader. In addition, assessments of achievement in this field must surely depend to some extent upon what particular nations can feasibly afford, and it might on that account be questioned whether all of those entities mentioned could not, in the light of their affluence, reasonably have contributed significantly more than they actually have.

The Biodiversity Convention itself sees the transfer of resources from the richer nations as being critical to conservation success, ${ }^{97}$ and Wandesforde-Smith interprets this as a movement 'from places where wildlife protection is highly valued to places

and preserve the environment and to enhance the means for doing so'. Note also the 2000 Cotonou Partnership Agreement between ACP and EC States, (2000) OJEC L317/3, especially Articles 1, 9, 32.

93 Viewable at <http:www.un.org/sustainabledevelopment/sustainable-development-goals>; see especially Goals 14 and 15.

94 Target 7.B, Goal 7, viewable at <http://www.un.org/millenniumgoals/>.

95 Wandesforde-Smith (n 11), 89, footnote 31.

96 Ibid.

97 This concern is in fact pervasive throughout the Convention, but see especially Article 20(4). 
where it is less so' ${ }^{98}$ Others, however, may see the matter as turning more on the relative ability of different states to fund the measures which they might ideally deem desirable, and on that account, for instance, to judge Kenya's decision in 1989 to destroy its ivory stockpile and forgo the considerable income it might have earned from it as indicative of very substantial conservation commitment. ${ }^{99}$ It might equally be recalled, again simply by way of example, that it was the government of India that, through repeated promptings, secured formal recognition (albeit in rather equivocal terms) of the legitimate interests of other life-forms at the Stockholm Conference, ${ }^{100}$ Zaire (as it then was) that spearheaded the project leading to the adoption of the World Charter for Nature 10 years later, ${ }^{101}$ Costa Rica that has designated over 25 per cent of its land mass as protected areas ${ }^{102}$ and Bolivia that triggered the current UN programme concerning elaboration of the idea of harmony with nature. ${ }^{103}$ Conservation commitment of sorts can actually be found right across the international community, but is seldom as robust or consistent anywhere as might be judged ideal.

\subsection{Legal Implications of Community Commitment}

In addition, there are other, more subtle and specifically legal, senses in which it is appropriate to attribute the source of pressure for biodiversity conservation, however it is specifically manifest, to the international community as a whole rather than to some particular faction within it. This assignment of substantive sponsorship is in fact appropriate whenever a particular conservation programme becomes enshrined in legal form at the transnational level, since, once that process has been completed through the creation and assumption of appropriate legal undertakings, a new consortium of underwriters is automatically brought into the picture. This occurs for the simple reason that the more fundamental commitment to legal commitment as such - i.e., to the rule of law in international affairs - is not only dependent upon, but actually commands (in repeatedly reaffirmed fashion) the support of the entire community, and not just the environmental faction within it. ${ }^{104}$ Indeed, within this broader polity, there would seem to be no politically significant entity, agency or constituency (however defined or

98 Wandesforde-Smith (n 11), 91.

99 For discussion of this incident, see R Leakey and V Morell, Wildlife Wars (St Martin's Press, 2001). Since that time, various other states have of course followed that example, most recently Ethiopia, as to which, see <http://www.bbc.uk/news/world-africa-31983727>.

100 See LB Sohn, 'The Stockholm Declaration on the Human Environment' (1973) 14 Harvard International Law Journal 423, 459.

101 See further Burhenne and Irwin (n 55).

102 C Runyan, 'Forever Costa Rica' Nature Conservancy Magazine (Arlington, VA) June 2011.

103 See the dedicated UN website at <http://www.harmonywithnatureun.org/>.

104 The point is made, for example, both in the first recital of the preamble to the UN Charter, and in its first substantive provision. It is dealt with more substantively in UNGA Resolution 2625 (XXV), the 1970 Declaration on Principles of International Law concerning Friendly Relations and Co-operation among States in accordance with the Charter of the United Nations. See further UNGA Resolution A/RES/44/23, of 17 November 1989, on the United Nations Decade for International Law. 


\section{Research handbook on biodiversity and law}

described) that seeks positively to deny, at least as a matter of abstract principle, the validity and importance of such commitment.

Accordingly, once any particular legal obligation is formally created in the environmental (or indeed in any other) field, it automatically attracts the support of the pre-existing and collectively endorsed constitutional infrastructure comprising the principles of state responsibility and, wherever the duty in question is couched in treaty form, the law of treaties. As a result, certain forensic opportunities for securing adherence to the commitment in question potentially become available. These possible sources of redress are, of course, overlaid upon whatever inducements to performance whether in the form of carrots or sticks - may be available under specific MEA regimes themselves. Thus, in the recent Antarctic Whaling case, ${ }^{105}$ the International Court of Justice (ICJ) made it clear that its decision should not be understood as an attempt to align itself with any of the sharply divergent perspectives on the environmental, scientific or ethical issues involved in the conduct of whaling, but only as an application of the general rules governing the implementation and interpretation of treaties, ${ }^{106}$ which, as suggested above, can for most practical purposes be regarded as having received the endorsement of the international community as a whole. ${ }^{107}$

This process of collective underwriting is, moreover, significantly intensified whenever the substantive commitment in question is recognised as being grounded not merely in the particular interests of individual states, but in the shared interests of a certain group, or indeed of the community as a whole. In this vein, the 1946 Whaling Convention (ICRW), which was the treaty in issue in the Whaling case, explicitly recognised 'the interest of the nations of the world' in safeguarding whale stocks, ${ }^{108}$ and accordingly permitted participation in the regime by any state, whether personally engaged in whaling or not. ${ }^{109}$ In the modern context, the collective nature of the interest in the performance of conservation commitments might arguably be assumed even in the absence of express confirmation by the individual treaty in question, since it would seem that the conservation of biological diversity has been authoritatively declared to represent the 'common concern of humankind' as a matter of general principle. ${ }^{110}$

105 Whaling in the Antarctic (Australia v Japan; New Zealand intervening), Judgment of 31 March 2014, ICJ.

106 See in particular paragraph 69 of the Judgment.

107 The substantive principles embodied in the 1969 Vienna Convention on the Law of Treaties, 1155 UNTS 331, are widely understood to represent contemporary customary international law (whether through codification or progressive development) and regularly applied as such, and largely regardless of whether the states in question have formally become parties to it.

1081946 International Convention for the Regulation of Whaling, 161 UNTS 72, first preambular recital.

109 Article $\mathrm{X}(2)$.

110 CBD, preamble, third recital. For further consideration of this notion, and of its legal implications, see the chapter by Duncan French is this volume. Note also the affirmation, 20 years earlier, in the World Heritage Convention (n 49) that 'it is incumbent on the international community as a whole to participate in the protection of the ... natural heritage of outstanding universal value': preamble, seventh recital. 
This recognition has served only to bolster certain ideas of community interest that are already evident within the law of state responsibility, ${ }^{111}$ and bear upon the ease with which it may be invoked against a delinquent state. Specifically, a breach of duty may be challenged (i) in a representative capacity, by any state to whom the duty is owed, ${ }^{112}$ or (ii) in the more specific capacity of 'injured state', by any party within that group which is specially affected, or where the position of all group members with respect to further performance is radically transformed. ${ }^{113}$ In either case, the state in question may demand cessation of the wrongful act and performance of the obligation of reparation. ${ }^{114}$ The implications of these provisions are therefore such as to create considerable opportunities for any individual state with a sufficiently strong commitment to appoint itself as a guardian of conservation or other community interests on an ad hoc basis. Thus, in the light of their recent application by the ICJ to a treaty concerning accountability for torture in the case between Belgium and Senegal regarding the Obligation to Prosecute or Extradite, ${ }^{115}$ Japan did not even consider it worthwhile challenging Australia's legal standing to complain of a breach of the ICRW by Japan in the Whaling case itself.

A further significant aspect of the case for present purposes concerned the decision by New Zealand to intervene in the proceedings in order to make representations regarding the proper interpretation of the Whaling Convention, as all contracting parties to a multilateral treaty which is in issue in proceedings before the ICJ are entitled to do. ${ }^{116}$ In the course of a very fully elaborated opinion on the matter, ${ }^{117}$ the Brazilian member of the Court, Judge Cançado Trindade, recognised this right as a vital means of diluting the heavy 'bilateralist bias that permeates dispute settlement under the procedure before this Court', ${ }^{118}$ a transformation which was essential where the dispute related to 'domains of concern to the international community as a whole'. ${ }^{119}$ There

111 As to which, see the 2001 Articles on Responsibility of States for Internationally Wrongful Acts, formulated by the International Law Commission and available via its website at $<$ http://www.un.org/law/ilc/> or from its Report of the 53rd Session, ILC (2001), GAOR 56th Session, Supp. 10.

112 Ibid., Article 48.

113 Ibid., Article 42.

114 The key distinction is that only an injured state may demand reparation in its own interest; others may do so solely in the interest of the injured state or other beneficiaries of the obligation breached: Article 48(2)(b).

115 (2012) ICJ Reports 422. The treaty in question was the 1984 UN Convention against Torture and Other Cruel, Inhuman or Degrading Treatment or Punishment, UN Doc A/Res/39/ 46; (1985) 23 ILM 1027, (1986) 24 ILM 535. Having determined Belgium's entitlement to institute proceedings simply by virtue of its participation in the treaty, the Court found it unnecessary to consider its further, more specific, claim to be an 'injured state': see especially Part III of its judgment, paras 64-70.

116 See Article 63, Statute of the International Court of Justice. Note also Article 62, which provides that any state which considers that it has an interest of a legal nature which may be affected by a decision can request to be permitted to intervene.

117 The opinion may be located via the 'Incidental Proceedings' link in the entry for this case on the Court's website.

118 See para. 71 of his Separate Opinion on the Declaration of Intervention.

119 Ibid., para. 66. 
was no doubt that the present case fell into that category, since 'The general policy objectives under the ICRW were ... - and remain - the protection of all whale species from overfishing, to the benefit of future generations in all nations, and the orderly development of the whaling industry was to abide by that'. ${ }^{120}$

He further emphasised the fact that the preambular reference to the whaling industry was expressed in terms of its orderly development rather than its development as such, indicating that its activities in the future were to be constrained by the collective interest in preserving the good order of the oceans through the adoption of proper mechanisms of conservation and the avoidance of conflicts or disputes, the "mere profitability' of the industry having been discarded as an objective. ${ }^{121} \mathrm{He}$ duly concluded by hailing the 'resurrection' of the right of intervention in recent years as a most welcome development, "propitiating the sound administration of justice ... , attentive to the needs not only of all states concerned but of the international community as a whole, in the conceptual universe of the jus gentium of our times'.122

In the light of these considerations, now would seem to be the least appropriate time imaginable to abandon commitment to the notion of the 'international community' as the underlying guarantor of conservation commitments and to reduce the project to the private fief of some ill-defined faction called the 'international environmental movement': however the matter may appear when viewed through the prism of political science, there can be no doubt of the continuing (and indeed growing) importance of community commitment to conservation from a strictly legal perspective. In this context, it is at last arguably appropriate to assert that we are all environmentalists now, at least in principle. Indeed, since the most fundamental objective of the international law of conservation is essentially to preserve the life support systems of the planet, it is difficult to see what rational grounds could exist for any particular constituency to seek to exempt itself from the project. ${ }^{123}$

At this juncture, however, it might well be objected that it is only in the very rare event of a dispute regarding the application or interpretation of a conservation treaty coming before an adjudicative body such as the ICJ that such a degree of attention is likely to be focused upon the precise nature and content of the legal commitments entailed, and that it would therefore be unwise to set too much store by any pronouncements that are generated in the process, especially since they will only produce binding effects for those states that were directly involved in the litigation

120 Ibid., para. 60 (emphasis added).

121 Ibid., para. 58. This should not, of course, be understood to imply that the prosperity of the industry was now to be regarded as entirely irrelevant: rather, it was effectively demoted from the status of an (indeed, the sole) objective, as it had been in the earlier 1937 Convention, to merely one factor to be taken into account in the fixing of quotas by the IWC: see Article V and especially para (2)(d) of the ICRW. These arguments had all been explored at much greater length in Bowman (n 32), which was cited by Judge Cançado Trindade in paragraph 71 of his further individual opinion delivered at the merits stage of the case.

122 Para. 68, Individual Opinion regarding Intervention.

123 Needless to say, this does not exclude the possibility that a host of imperfectly rational or blatantly irrational reasons may be raised in relation to particular projects or situations. 
process itself. ${ }^{124}$ There is no doubt some force in this point, ${ }^{125}$ but there are also a number of countervailing considerations that should be borne in mind.

The first of these is that, whatever the formal limitations of the applicability of judicial decisions, in the modern context the echoes of any such judgment are sure to be heard far beyond the confines of the courtroom itself: it is difficult to believe, for example, that any International Whaling Commission (IWC) member that was minded to issue permits for scientific whaling would henceforth feel able to disregard altogether the considerations spelled out by the ICJ with regard to the interpretation in good faith of the relevant provision of the ICRW, Article 8. ${ }^{126}$ Indeed, New Zealand has already secured the adoption of a resolution at the most recent meeting of the IWC, which was broadly designed to give effect to the key legal pronouncements of the Court. ${ }^{127}$ Furthermore, the mere fact that issues concerning the conservation of biological diversity are now thought sufficiently important to generate litigation before the World Court serves of itself to heighten the profile of this area of policy concern in a more general way.

Secondly, and in reinforcement of the previous point, all the signs are that the incidence of such litigation is only likely to intensify in the future, ${ }^{128}$ especially bearing in mind that the ICJ does not stand alone here, in the sense that the roll-call of judicial, quasi-judicial and arbitral tribunals available to process cases grounded upon the international responsibility of states in an environmental context has significantly increased of late. ${ }^{129}$ Recent years have even witnessed the establishment by the Security Council of a wholly new institution designed to address on a purely ad hoc basis the legal consequences of the illegal Iraqi invasion of Kuwait in 1990, a

124 That is to say, the actual parties to the litigation themselves, together with any state that opts to intervene in the case on the grounds that it is a party to a Convention which is in issue: ICJ Statute, Articles 59, 63.

125 It seems, for example, that states other than Great Britain and the US that were involved in the exploitation of fur seals felt little compunction in ignoring the implications of the arbitral decision in the Bering Sea Fur Seals case (1898) 1 Moore's International Arbitration Awards 755: see generally S Barrett, Environment and Statecraft: The Strategy of Environmental Treaty-Making (OUP, 2005), chapter 2.

126 Japan itself has already submitted a revised proposal which was intended to be compliant: see the Circular IWC.ALL.220 of 19 November 2014, 'Government of Japan: New Scientific Whale Research Program in the Antarctic Ocean', available on the IWC website at $<$ http://iwc.int/circulars $>$.

127 Resolution 2014-5, on Whaling under Special Permit. It must be conceded that this resolution was ultimately adopted only by 35 votes to 20 , with five abstentions. It should also be recognised, however, that its failure to secure universal endorsement may well be attributable to the fact that, as observed by various states and accepted by NZ, it went beyond the strict terms of the judgment in certain respects.

128 Note in this regard the consolidated cases currently pending before the ICJ between Costa Rica and Nicaragua, where each complains of a violation of the Ramsar Wetlands Convention.

129 In addition to the forums noted in the text below, the International Tribunal for the Law of the Sea (ITLOS) represents a notable example. 
development which has generated, inter alia, a mass of valuable precedents concerning the definition and valuation of environmental harm. ${ }^{130}$

In addition, the undeniable residual reluctance of states to institute international legal proceedings on their own behalf in respect of environmental harm may sometimes be circumvented by the recruitment or intervention of other agencies. In the case of the long-running saga concerning the Greek government's failure to fulfil its obligations under the Bern Convention with regard to the protection of turtle nesting sites at Laganas Bay, Zakynthos, for example, the nascent proposal by a small consortium of states to institute arbitration proceedings against Greece under the terms of Article 18 of that treaty was ultimately abandoned only in light of the willingness of the European Commission to institute proceedings for breach of the EU Habitats Directive - an option which also permitted access to the stronger remedies and enforcement mechanisms of EU Law. ${ }^{131}$

In other instances, the route to enforcement may be rather less direct and obvious. The government of Tanzania, for example, may possibly have anticipated the criticism to which it was subjected within the World Heritage Committee in 2010 on account of its proposal to develop an all-weather, bitumenised trunk road across the Serengeti National Park, since this was designed largely to stimulate economic growth in the surrounding regions and threatened significant harm to the park itself, a World Heritage site. ${ }^{132}$ It may have been more surprised, however, to find itself subsequently instructed by the East African Court of Justice to abandon the project in its original form, as a result of proceedings instituted by an African animal welfare organisation. ${ }^{133}$ Yet this decision was squarely based upon provisions of the East African Community Treaty which required partner states to co-ordinate their economic and other policies to the extent necessary to achieve Community objectives, and to promote the sustainable utilisation of their natural resources and the taking of measures designed to preserve, protect and enhance the quality of the natural environment. ${ }^{134}$ It is therefore clear that,

130 For details, see the website of the UNCC at <http://www.uncc.ch $>$.

131 For discussion, see Lyster, 342-344.

132 See World Heritage Committee Decision 35 COM 7B.5, which envisaged the possibility of irreversible damage to the property's outstanding universal value in the absence of a suitable environmental impact assessment. See further Decision 36 COM 7B.6 of 2011, in which the Committee welcomed Tanzania's decision in response to seek funding for a Strategic Environment and Social Assessment for the road.

133 African Network for Animal Welfare v A-G, Utd Republic of Tanzania, Reference No 9 of 2010, Judgment of 20 June 2014, available via the website of the East African Community at $<\mathrm{http}: / /$ www.eac.int/>. Its right to undertake other programmes or policies which would not impact negatively on the environment and ecosystem of the Park was, of course, explicitly preserved. This was not seen to exclude some upgrading of the existing track for the purposes of tourism and park administration, a project towards which Tanzania itself now seemed to be inclining in any event.

1341999 Treaty for the Establishment of the East African Community, text also available via its website, ibid. These obligations were generated by a combination of Articles 5(3)(c), 8(1)(c), 111(2) and 114(1). The fact that a later Protocol designed to give more concrete and detailed expression to these environmental commitments was not yet in force was not regarded as material. It is noteworthy that the court envisaged possible adverse effects not only on the Serengeti itself, but also on the neighbouring Masai Mara Park in Kenya. 
even in the realm of an arrangement designed primarily for economic development, the commitment to conservation was not seen as mere window-dressing.

Yet, for all that, it would plainly be as much of an error to overstate the practical impact of these natural concomitants of international legal obligation as to overlook them altogether. Not only will the contribution of international courts and tribunals to the consolidation of conservation commitment remain relatively modest, it may also be further diluted by the possibility that disputes regarding the application of legal measures designed for conservation purposes may actually fall to be litigated within tribunals that perceive their most important policy priorities to lie elsewhere, and whose technical expertise is accordingly focused upon different areas of law entirely. ${ }^{135}$ The vital need is therefore to prompt wide-ranging institutional action designed to counter the substantive fragmentation that is currently evident amongst these various bodies of norms, through the far more effective integration of the particular rules they contain.

As noted above, this integrative process is already under way in a formal sense. It is, of course, mandated in rudimentary fashion by the law of treaties itself, in the form of Article 31(3)(c) of the 1969 Vienna Convention, by which the process of treaty interpretation is to be informed by the principle of 'systemic integration' of legal norms generally. ${ }^{136}$ In most cases, however, this minimum requirement is overlain by explicit provision in the key treaties themselves, which typically allows for (though without necessarily securing in practice) some more sophisticated mode of accommodation to occur. ${ }^{137}$ The problem of fragmentation generally has, of course, been the specific subject of formal investigation by the International Law Commission, ${ }^{138}$ though a case could certainly be made that this represents one of their least impressive and successful enterprises to date.

Accordingly, if there is one vital goal to which legal research and scholarship might most profitably be directed it would be the advancement and acceleration of this process of harmonisation and reconciliation between the general principles of biodiversity conservation and those governing other key areas of international endeavour, such as economic development, international trade, human rights and the protection of international peace and security. ${ }^{139}$ Needless to say, this point has already been widely recognised in an abstract sense, being enshrined in the principle of integration, which

135 A particularly notable example can be found in the dispute settlement arrangements of the WTO, though even here the bodies in question have moved gradually towards the more meaningful recognition of the sustainable development ideal (which is, after all, explicitly enshrined in its preamble). For an overview of the significance of litigation in the environmental field, see Birnie, Boyle and Redgwell (n 56), 250-262.

136 For discussion, see C McLachlan, 'The Principle of Systemic Interpretation and Article 31(3)(c) of the Vienna Convention' (2005) 54 ICLQ 290; D French, 'Treaty Interpretation and the Incorporation of Extraneous Legal Rules' (2006) ICLQ 281-314.

137 See, for example, CBD, Article 22; CITES, Article 14; CMS, Article 12.

138 For details of the Commission's programme of work, see its website at <legal.un.org/ilc/ guide/1_1.htm>.

139 The importance of legal scholarship in the development of international conservation law was explicitly acknowledged by the Brazilian judge, Judge Cançado Trindade, in para. 71 of his individual opinion in the Whaling case (n 105). 
finds reflection in the Rio Declaration and other key instruments. ${ }^{140}$ Yet the undeniable reality is, regrettably, that this principle has itself not yet been fully integrated into the international legal order, or adequately reflected, respected and consolidated into the practice of international society, in either its governmental or non-governmental dimension. The principal focus of attention across the majority of areas of political activity is still almost invariably upon some very obvious and immediate - albeit commonly less essential - matter of human concern, whereas our absolute ultimate dependence upon the ecosystem services that other species and their interactions provide for us is something that requires a significantly more sophisticated, wellinformed and reflective form of appreciation. ${ }^{141}$

To the extent, therefore, that there is currently an unmet requirement for the bringing to bear of a 'vision' of some kind, it would seem to relate to the means by which the imperative of biodiversity conservation can be woven more effectively into the fabric of global policy and practice. The key question accordingly becomes: what precise form should this vision ideally take? This is not, unfortunately, a question that can be answered with any certainty on the basis of Wandesforde-Smith's own account, for his pronouncements on the matter are decidedly Delphic.

\section{THE ENVISIONING OF VISION ITSELF}

One factor which contributes particularly to this ambiguity concerns the way in which his discussion appears to drift casually between the language of international law and international politics without any apparent need being felt for the establishment of any obvious lines of demarcation between the two. ${ }^{142}$ This deficiency is a significant one, for, while the international politics of conservation plainly subsumes all the various elements of legal regulation that involve a supra-national dimension, it at the same time constitutes a much wider field of human endeavour, embracing many other forms of transnational activity. The World Conservation Strategy, for example, was a sophisticated attempt by a consortium of international organisations to elaborate a strategy for harmonising the goals of economic development and environmental protection, and setting out the means by which they might realistically be achieved. It does not of itself constitute law in any sense, however, since it is couched in descriptive and programmatic rather than normative terms. ${ }^{143}$ The utilisation of legal measures is of course discussed, but only as one of the various means that might be employed to implement the strategy. ${ }^{144}$ In similar fashion, the articulation of 'Proposed Legal Principles for

140 See, for example, Rio Declaration, Principle 4; Stockholm Declaration, Principle 13; World Charter for Nature, Principle 7.

141 Note in this context the potential contribution of IPBES (n 24).

142 That being so, it is especially surprising to encounter within it (Wandesforde-Smith (n 11), 90) a complaint that 'it is striking in the new book [i.e., Lyster] ... how little discrimination there is among all the arenas or fronts in which the international politics of wildlife are played out', since that is exactly the charge that might justly be levelled against the reviewer himself.

143 That said, it does of course form an important part of the policy backcloth onto which all subsequent legal developments should sensibly be projected.

144 See especially chapter 15 , which is merely one of 20 chapters in all. 
Environmental Protection and Sustainable Development' appeared as only one element within the report of the Brundtland Commission. ${ }^{145}$

In international affairs, accordingly, law must be seen as only one of the many factors which serve to shape human conduct, much of which is scarcely affected by it at all, except perhaps in the negative sense that there is no explicit legal prohibition of the behaviour in question. Indeed, where ordinary private citizens are concerned, law of the public international variety is likely to appear especially peripheral and remote. Thus, in the particular field of conservation, it would be possible for a committed individual to engage in a lifetime of dedicated activity without overtly having to confront it at all. This commitment might take any one of a number of forms, including educating others in the practical importance of conservation, exploring and developing the scientific understanding through which it can be accomplished, participating in the maintenance or management of wildlife reserves, fund-raising for conservation activities or simply re-organising one's own personal lifestyle in such a way as to reduce the material demands it imposes upon the natural environment.

In the light of these considerations, it is surely bizarre to suggest, as WandesfordeSmith appears to do, ${ }^{146}$ that an environmental activist wishing to obtain guidance regarding what they should do next could sensibly expect to secure an answer from a monograph on international law! Such a work is intended neither as a clarion call to conservation action, nor as a practical manual for everyday activism - functions which are, after all, now amply served by numerous other publications. ${ }^{147}$ Accordingly, the only reasonable response to someone who made the mistake of seeking enlightenment of this sort from a book like Lyster would be to echo the one helpfully offered by the apocryphal bystander, when asked by a would-be traveller for directions to the railway station: 'If I were you, I wouldn't start from here!'

\subsection{Understanding the Roles of Actors in the International Legal Order}

None of this should be taken to suggest, however, that the legal regime governing biodiversity conservation globally is of no importance or interest to individuals or other non-state entities, or even that they have no direct or significant role to play within it. To the contrary, Wandesforde-Smith is quite correct to note the substantial transformation that has occurred over the course of the last century with regard to the agencies through which the various activities that fall within the purview of international law are characteristically conducted. Although commerce and other forms of economic, social

145 WCED, Our Common Future (OUP, 1987); see especially chapter 12 and annexe I.

146 See Wandesforde-Smith (n 11), especially 92-93.

147 For a brief sample of the numerous publications of this kind which are now available: see the Sierra Club's Grassroots Organizing Training Manual (Sierra Club, 1999); M Hawthorne, Striking at the Roots: A Practical Guide to Animal Activism (Changemakers Books, 2007); A Ricketts, The Activists Handbook (Zed Books, 2012); J Perlman, Citizen's Primer for Conservation Activism (University of Texas Press, 2014). Entire PhDs have in fact been written on the subject simply from the perspective of one particular country: for an example, see RB Wilcox, The Ecology of Hope: Environmental Grassroots Activism in Japan (Union Institute \& University College of Graduate Studies, 2004), available at <http://www9.ocn.ne.jp/ asian/ ecohope.pdf>. 
and cultural co-operation between individuals, corporations and other private sector bodies have long been pursued on a transnational basis, and sometimes on a truly massive scale, ${ }^{148}$ the vast bulk of international intercourse was traditionally conducted through the diplomatic organs of national government. During this period, the 'international community' was accordingly viewed as being essentially a community of states (and a rather small number of them at that), and the legal order by which it was served was therefore typically characterised as the law of nations. ${ }^{149}$ In more recent times, however, the nature of this political community and legal order has been radically reconfigured through a series of significant developments, including (i) the vast proliferation of inter-governmental organisations that have come to assume technical or political functions on behalf of the community as a whole, (ii) the direct conferral of legal personality on individual human beings as a consequence of the recognition and development of the human rights regime and (iii) the emergence of NGOs as major players in many of the most important areas of international political activity.

In the wildlife field, NGOs have come to occupy a particularly crucial role, and to fulfil a vast array of functions which would once have been thought far beyond their remit or capacity. Thus, they have not only agitated for the adoption of treaty arrangements, but actually undertaken a major role in the drafting process itself; they have not simply monitored states parties in the performance of their conservation commitments but sometimes secured the opportunity to incorporate the results of this supervision within formal treaty compliance procedures; they have provided the initiative, expertise and resources that were required to make particular substantive conservation projects a reality; they have been allocated decision-making functions for the purpose of certain regimes and even provided secretariat services on occasion; in some cases, to conclude, they have been granted formal 'partnership' status that guarantees them, inter alia, a place at the table of every key committee that operates within the regime in question. ${ }^{150}$ Accordingly, any account of the contemporary conservation regime is bound to make extensive reference to their involvement.

Yet for all that there have been certain features of the legal system which have remained essentially unchanged: most importantly, states themselves have never relinquished control of either the mechanisms of law-making or the processes through which legal personality is formally recognised, with the result that their traditional stranglehold over the legal order has been to a considerable extent retained. ${ }^{151}$ Thus, when such organisations as IUCN, ICBP and the International Waterfowl Research

148 Perhaps the most obvious instances are provided by the para-statal activities of bodies such as the Dutch East India Company during the 17th and 18th centuries.

149 Thus JL Brierly's celebrated text, first published in 1928, has that as its very title (see now the 7th edition, by Andrew Clapham, published by OUP in 2012).

150 See generally Sands \& Peel (n 57), 86-92 and the literature there cited. The Ramsar Convention - on which see Lyster, chapter 13 and GVT Matthews, The Ramsar Convention on Wetlands: Its History and Development (Ramsar Bureau, 1993) - provides a particularly instructive case study in all the respects mentioned.

151 Accordingly, Jutta Brunnée treats this fundamental truth as the very starting point of her discussion of the means by which international environmental law might ultimately be deployed to address 'the global concerns of humanity as a whole': see her 'Common Areas, Common 
Bureau began to agitate during the 1960s for a reversal of the progressive loss of wetland habitat that was beginning to imperil the survival prospects of numerous species of birds, they immediately recognised that they would be unable to make significant substantive headway without sponsorship and support from states that were sympathetically disposed towards the project. Fortunately, this was in the event forthcoming from certain key quarters, including most notably the Dutch and Soviet governments, which worked with them on successive drafts of a treaty text, and that of Iran, who proved willing to host the diplomatic conference at which the evolving instrument was finalised and opened for signature. ${ }^{152}$ No less importantly, some 23 governments actually turned up to attend this event, without which the entire project would have remained still-born in normative terms. ${ }^{153}$

Of course, given the vital role that these NGOs had played in the drafting and development of the agreement in question, it could hardly have been expected that they would thereafter simply stand back to watch passively how events unfolded. To the contrary, the intention was always that they would continue to participate directly in its ongoing implementation, and provision was therefore made for the convening of periodic conferences at which progress could be monitored by all the key stakeholders. ${ }^{154}$ Yet the non-governmental bodies within this group would inevitably remain dependent upon the degree of latitude that governments themselves were prepared to grant them in that regard: full, front-line participation as of right in this Convention for wetland conservation would naturally only be open to statal entities, ${ }^{155}$ since any other arrangement would inevitably have undermined the formal legal status of the entire agreement. Part of the reason for this, of course, is that it will be states themselves which, in formal terms, actually assume, and ultimately remain accountable for, the conservation responsibilities that such treaties impose.

The fact that, where law specifically is concerned, the formal primacy of governmental responsibility remains essentially unchanged seems largely to pass unnoticed in Wandesforde-Smith's analysis, and possibly stems from his failure to maintain a clear distinction between the political and the more narrowly legal aspects of international conservation endeavours. For example, he suggests at one point that

[i]n retrospect, Lyster's insistence that the political will of governments and their investments in what today we would call implementation capacity are the critical factors for wildlife has about it a starchy whiff of the formal institutional stiffness that used to characterize international law and international lawyers before 1945. While people in government are certainly still part of the starburst constellation of actors seeking to shape international

Heritage, and Common Concern' in D Bodansky, J Brunnée and EC Hey (eds.), The Oxford Handbook of International Environmental Law (OUP, 2008) 550, 551.

152 See generally the Final Act of the International Conference on the Conservation of Wetlands and Waterfowl (1971), available at <http://archive.ramsar.org/>, via the links 'Documents' and 'Conferences of the Parties'.

153 Though five of these attended purely in the capacity of observers: ibid.

154 Article 6, which was amended in 1987.

155 On the question of participation, see Article 9. 


\section{Research handbook on biodiversity and law}

wildlife law and its outcomes, the initiative and the balance of influence, if not power, now more often seems to lie with non-state actors. ${ }^{156}$

The observation seems open to question on a number of accounts. Read in context, Lyster's point was surely not so much that the political will and capacity of governments are the 'critical factors for wildlife', or even for its conservation, but rather for the much more specific question of the capacity of international law as such to make a contribution in that regard. As we have seen, international law is only one of the mechanisms and processes through which this objective might reasonably be pursued, and in many of these alternative modes of conservation activity the potential role of non-governmental agencies for the achievement of progress through their own unaided efforts may doubtless be considerably greater. Where international law itself is concerned, however, the role of governments will continue to be crucial, and would remain so even where (as may very well often be the case) they opt to place reliance upon the enthusiasm, initiative, expertise and resources of civil society in the course of discharging their responsibilities. Indeed, even a nation which goes so far as actually to delegate the performance of certain practical conservation functions to an NGO or other private sector agency will be obliged at the very least to equip itself with the powers needed to supervise the body in question, and, where necessary, to coax or coerce it into more effective action. For all their undoubted practical influence, non-state entities remain in the twilight zone of formal legal personhood on the international legal plane. In addition, the practical fulfilment of the conservation commitments imposed by treaty regimes will typically require the adoption of legal measures at the national level, and here again it is only states and governments that have ultimate capacity and authority in that regard. Consequently, Lyster's observations were not only perfectly apposite at the time of their publication, but remain so today.

As far as claims to have detected the 'whiff of starch' are concerned, ${ }^{157}$ there are surely strong grounds for questioning whether starch itself should ever be seen as something merely to be sniffed at - it is, after all, the very fuel of life itself! ${ }^{158}$ And while it would plainly be excessive to make this claim of international law as such, its potential impact on human behaviour does at least resemble that of starch in its processed form, in terms of its specific capacity to stiffen the fabric of whatever conservationist apparel we have seen fit to assume at any given moment; it is, indeed, for that very reason that those in the 'international environmental movement' have so frequently sought to invoke its authority and support. The system undoubtedly has a great many weaknesses, but there has always been a very significant difference between, on the one hand, the charge that a government has failed to follow an

\footnotetext{
156 Wandesforde-Smith (n 11), 86-87, reflecting on the observations of Lyster (n 10), 303-304.

157 Starch in its pure form is actually odourless, it would seem: see the website of AAF, the European Starch Industry Association, at <http://www.aaf-eu.org/portfolio/>.

158 Thus, it has recently been observed that starch, which is a carbohydrate produced by green plants as an energy store, 'remains at the very epicentre of the world's food and feed chains and has ... become one of the world's most important sources of biorenewable energy': PL Keeling and AM Myers, 'Biochemistry and Genetics of Starch Synthesis' (2010) 1 Annual Review of Food Science and Technology 271, Abstract.
} 
appropriate policy in some particular respect and, on the other, the allegation that it has failed to comply with a specific legal obligation.

If, therefore, the authors of the new edition of Lyster should appear to have decided - as Wandesforde-Smith suggests - to 'stick to their legal last', ${ }^{159}$ that will doubtless be because it is, after all, the law which constitutes the specific focus of their study. As it happens, moreover, the particular metaphor employed here seems more apposite than its creator may have realised, on the grounds that, where the fundamentals of the international legal system are concerned, we are indeed compelled for the time being to make do and mend with the cobbled-up normative order that we have inherited from our forebears. ${ }^{160}$ Since this system has encountered considerable difficulty even in tackling its most loudly proclaimed concerns, such as the eradication of torture or of military aggression, it is only to be expected that it will struggle to cope effectively with the more subtle, complex and wide-ranging challenges posed by environmental degradation. Yet while international law undoubtedly remains a relatively primitive system, it is this very trait which suggests not only that it might retain an inherent capacity for evolutionary advance, but also that the serious, systematic and scholarly exploration of its current strengths and weaknesses might have a significant part to play in this process of ongoing development. And since the law governing conservation is predominantly treaty based, it stands to reason that treaty regimes must form the primary focus of scholarly attention.

\subsection{Understanding the Role of Treaties in the International Legal Order}

Accordingly, as Wandesforde-Smith himself observes: ${ }^{161}$

Lyster put a focus on wildlife treaties. Now, twenty-five years later, there are more wildlife treaties than ever, and on top of that even more treaties addressing other global issues that have cross-cutting consequences for the future welfare of species and habitats. The new book comes to grips superbly with the details of this new legal reality in all of its complexity.

The authors will, I am sure, be extremely grateful for this generous endorsement of their efforts, especially since it suggests that the fundamental object and purpose of the book - namely to present 'a clear and authoritative analysis of the key treaties which regulate the conservation of wildlife and habitat protection, and of the mechanisms available to make them work' - has been amply achieved.

It seems, however, to be this very objective itself which the reviewer seeks to call into question, in suggesting that what the new edition

does not seem to grasp and certainly does not venture to say anywhere is that the great age of wildlife and environmental treaty making, the age gathering a full head of steam as Lyster set pen to paper, is over. The political and economic conditions that brought it into existence are

159 Wandesforde-Smith (n 11), 92.

160 For the benefit of any readers unfamiliar with the cobbler's craft, it may be helpful to point out that a 'last' is a device comprising a number of variously sized, foot-shaped projections upon which shoes may be securely placed for the purposes of repair.

161 Wandesforde-Smith (n 11), 93. 
gone and may not soon, if ever, return. Doing more of the same and lots of it is not, therefore, a realistic option. ${ }^{162}$

Once again, this claim requires a good deal of unpicking. First, it can certainly be acknowledged that no statement of the kind alluded to will be found in the new edition, though the reasons why its inclusion would never have been contemplated have more to do with the doubts that must be entertained regarding its substantive pertinence and cogency than with any other consideration. To begin with the less important reservation that might be maintained, the statement is of questionable factual accuracy on a number of counts. For one, to the extent that it actually matters to identify the precise 'heyday' of conservation treaty making, it would surely be the 1970s, rather than the late 1980s, that had the strongest claim: indeed, it was very probably the spate of key treaties that emerged during that period that originally prompted Simon Lyster to consider it worthwhile 'setting pen to paper' in the first place. ${ }^{163}$

Equally, although the flow of international 'legislative' activity has arguably slowed a little since the original appearance of his work, the negotiation and adoption of wildlife treaties certainly has not halted: ${ }^{164}$ most obviously, the Biodiversity Convention itself has been concluded, followed by three rather significant protocols and a separate treaty on plant genetic resources. This period has also witnessed the conclusion of important agreements on watercourses, mountains and forests and a revised version of the regional conservation regime for Africa, as well as a whole clutch of ancillary instruments adopted within the framework of the Migratory Species Convention. In addition, there has been a succession of crucial agreements addressing different aspects of fisheries conservation. A further noteworthy development, potentially heralding a new direction for wildlife protection, entailed the adoption of a treaty concerning individual animal welfare, conceived entirely independently of any threat to the survival of the species covered. ${ }^{165}$ Furthermore, even had the procreative process regarding new legal instruments actually ground to a halt entirely, the most plausible explanation could surely have been found in the fact that the great majority of the principal substantive contexts where protection is currently required (barring, perhaps, additional measures to address the needs of particular categories of migratory species) are probably now covered.

Yet this element of factual shakiness is largely overshadowed by the fact that the reviewer's assertion is almost entirely beside the point, for there is surely no one who would suggest that the explication and analysis of international wildlife law can somehow be reduced to a mere inventory of instruments adopted. To the contrary, what

162 Ibid.

163 On this point, see Lyster's own 'Introduction', xxi.

164 Indeed, this point is recognised by Wandesforde-Smith himself, as noted above. For a convenient snapshot of the ongoing programme of international treaty-making in the broad field of biodiversity conservation, together with text location references for the many instruments in question, including those mentioned in the text immediately following, see the 'Table of Treaties and Other International Instruments' in Sands and Peel (n 57), xlix-lix.

1651997 Agreement on Humane Trapping Standards, OJEC 1998 L042, approved by Council Decision 98/142. For discussion, see Lyster, 686-688; SR Harrop, 'The International Agreement on Humane Trapping Standards' (1998) 1 JIWLP 387. 
should form the proper focus of the attention of international wildlife lawyers is not 'the great age of wildlife and environmental treaty making' as such but rather the complex ongoing process of application and development of treaty-based regulation, which is a very much more wide-ranging phenomenon. Anyone who believes that this latter process has run out of steam has plainly not been paying sufficiently close attention. For the reality is that states continue to turn up in impressive numbers for the ongoing cycles of meetings of the Conferences of the Parties to these Conventions, to formulate and approve resolutions and recommendations regarding their interpretation and application, to devise and refine mechanisms and procedures for their more effective implementation and to support or participate in the many subsidiary bodies, committees and regional offshoot activities that the business of these regimes tends to generate. In addition, a great deal of time, effort and resources is being expended on the development of legal and institutional capacity to translate these international commitments into substantive progress on the ground at the national level. ${ }^{166}$ Furthermore, it seems scarcely appropriate to suggest, as the reviewer does, that this amounts simply to 'more of the same', ${ }^{167}$ because the tools, techniques, processes and procedures that are currently available for the environmental repair and restoration process are now of a decidedly superior order than those that were ever available to earlier generations.

This process effectively began, of course, with the incorporation into wildlife conservation treaties of institutional arrangements of the kind pioneered by Ramsar, transforming them into much more of an organic process, and thereby generating the potential for evolutionary change in the quality and quantity of normative responses to environmental problems. It is, however, only during the last few decades that these new institutional mechanisms have been established within the international community, ${ }^{168}$ and given the very slow pace of change in international legal affairs it is certain to take time before their potential can be explored and exploited to maximum effect. It is only in the light of considerations such as these that the real evolutionary potential of international wildlife law can properly be assessed.

The conviction that a very great deal is to be gained from the meticulous application to international wildlife law of the traditional techniques of legal scholarship is, moreover, only strengthened by consideration of Wandesforde-Smith's personal prescription for progress in this area, which appears to involve dedication to the pursuit of what he describes as 'interstitial headway'. ${ }^{169}$ Now it must first be observed that,

166 See, for example, UNEP, 'Implementation of MEAs in National Law', a Powerpoint presentation viewable at <http://www.iucnael.org/en/documents/631-unit-9-implementation-ofmeas-in-national-law/file>; GL Rose, 'Gaps in the Implementation of Environmental Law at the National, Regional and Global Level' (2011), available at <http://www.unep.org/delc/Portals/ 24151/FormatedGapsEL.pdf>; S Maljean-Dubois and L Rajamani, Implementation of International Environmental Law (Brill, 2011); A Chandra and A Idrisova, 'Convention on Biological Diversity: A Review of National Challenges and Opportunities for Implementation' (2011) 20 Biodiversity and Conservation 3295.

167 Wandesforde-Smith (n 11), 93.

168 Institutional arrangements have, admittedly, been a feature of fisheries treaty regimes for rather longer, but the precise nature of those arrangements has always left a great deal to be desired.

169 Wandesforde-Smith (n 11), 94. 
coming as it does from one who has specified as a key aim of legal scholarship the provision of a rallying cry to inject renewed impetus into environmental activism, this is scarcely the most inspirational of slogans. Part of the difficulty here, no doubt, lies in the obscurity of the concept itself, a problem that is compounded by the fact that its promulgator omits to offer any concrete illustrations to shed light on the matter. Only the following general explanation of the idea is presented: ${ }^{170}$

This is the pursuit of initiatives that give the law new leverage and power by discerning and exploiting in the nooks and crannies of the law as it stands, and of the regimes it has already created, chances to put the pressure on, in Lyster's phrase, in fresh and unexpected and, therefore, potentially productive ways. It might come from framing problems in a new legal light or by putting before established institutions legal options to act in ways that they have not previously considered as within their remit.

It is at this point that one might reasonably conclude that what is being marketed here is essentially old wine in an old bottle, but under cover of a new label. For opportunities of the kind envisaged are exactly what might be expected to be unearthed by the systematic legal analysis of conservation treaty regimes, and in particular the arrangements for their implementation. This was, of course, precisely the reason why it was decided to incorporate an entirely new chapter concerning implementation and enforcement in the opening section of Lyster, and to greatly expand the attention devoted to such matters in the majority of the individual chapters. In each case, furthermore, due attention is given to the role of private sector actors in this context alongside that of states parties themselves. ${ }^{171}$

None of this, however, should be taken to suggest that the broad approach adopted in Lyster towards the structuring of its subject-matter - essentially a regime-by-regime analysis of international wildlife treaties, bolstered by the presentation of various cross-cutting issues and underlying contextual commonalities - represents the only legitimate way in which the topic can be addressed. To the contrary, there is a most vital and urgent need for the compilation of works which adopt alternative and complementary approaches, and in particular those which delve more deeply into the practical efficacy of particular treaty initiatives, identify and analyse more fully the recurrent themes and problems which pervade the regulatory landscape of conservation conventions generally, explore the many interfaces of international wildlife law with other specialist areas of legal concern, and evaluate its role and contribution within the international legal order as a whole. It is, indeed, precisely with these matters in mind that this present Research Handbook was conceived in the first place. Accordingly, it is hoped that it may serve as a modest means both of establishing and of advancing a regulatory vision and agenda for the future.

170 Ibid.

171 For a brief and random sample of references to opportunities for private sector actors to influence outcomes, see pp. 101-106, 111-112, 161, 183, 227, 371-372, 443, 476-477, 504, 565-566, 644, 677-678. 


\section{CONCLUSIONS: 2020 VISION AND BEYOND}

In the light of all the above considerations, it should be possible to develop some sort of viable 'vision' for international wildlife law which can be drawn upon to guide the development both of the legal regime for the global conservation of biological diversity and the growing body of legal scholarship through which it is elucidated. In the first instance, this should entail the abandonment of any hopes for grand epiphanies, smart dodges or quick and easy solutions, and the continued dedication to work of a more grounded, potentially gruelling and unflaggingly meticulous character. More specifically, these endeavours should remain focused upon the deployment of traditional legal skills to best advantage in the thorough and thoughtful analysis and evaluation of the principles, practices and processes through which the conservation of nature is addressed and effectuated on the international plane. There is ample evidence that those charged with organisational responsibility for the implementation of the treaties in question will pay heed to serious scholarship which successfully exposes weaknesses and inconsistencies in or amongst the regimes in question. ${ }^{172}$ There is, moreover, a long tradition of treaty bodies actively commissioning formal legal opinions on issues of current controversy and concern. ${ }^{173}$ Elsewhere within the legal community, the members both of international courts and tribunals and of law reform agencies such as the International Law Commission have also shown themselves to be receptive to the lessons taught by legal scholarship. ${ }^{174}$ The slowly growing impetus generated by such processes is now just beginning to enhance the profile of international environmental law, including that relating to the conservation of biological diversity.

As noted above, this enhanced sense of priority and understanding may ultimately prove to be of greatest significance in relation to the task of achieving a more effective accommodation of conservation interests with cognate areas of international law, as reflected above all in the regimes which govern such matters as international trade, the international economy, peace and security, and human rights. Although these have all traditionally been accorded a much higher priority than environmental protection, the realisation is very gradually beginning to dawn that none of the aspirations by which these regimes are motivated is remotely capable of achievement unless the life support

172 The Ramsar Secretariat, for instance, began to publish examples of externally generated legal research relating to the Convention on its website in 2002, and the CoP definition of wise use was changed at its next meeting, partly with a view to achieving a better articulation between Article 3(1) and 3(2), a matter which had been the focus of considerable concern in the literature.

173 The IWC, for example, has commissioned a number of opinions on legal questions, several of which are discussed in C Wold, 'Legal Opinion on the Competence of the IWC to Include Humane Treatment and Human and Cetacean Health Concerns in the RMS', 21 June 2000, available at <http://www.lclark.edu/live/files/183>.

${ }_{174}$ As regards the ICJ (which has been sparing in its explicit reference to doctrine), see Article 38(1)(d) of its Statute and M Peil, 'Scholarly Writings as a Source of Law: A Survey of the Use of Doctrine by the International Court of Justice' (2012) 1 Cambridge Journal of International \& Comparative Law 136-161. As regards the ILC, a perusal of its reports reveals extensive reference to legal scholarship, which has proved influential in relation to the question of environmental liability, for example. 
systems of the planet can be effectively assured. Thus, organisations such as the World Bank and the WTO have already taken some preliminary, tentative steps towards the more effective recognition of environmental protection as a cornerstone of sustainable development, while lawyers specialising in human rights and the use of force are very belatedly coming to realise the extent to which all their traditional efforts can effectively be set at naught by the ravages of environmental insecurity. As yet, however, the practitioners of these disciplines have barely begun to recognise the overriding importance of, still less to engage in any meaningful way with, the specific question of biodiversity conservation, or with the principles and processes through which it can best be secured. ${ }^{175}$

\subsection{Discarding the Blinkers of the 'Enlightenment' Worldview}

As suggested above, one of the principal challenges in this context undoubtedly derives from the extent to which the current global societal order, together with the academic disciplines by which it is ultimately underpinned (most notably politics, philosophy and economics) have remained trapped in the intellectual stranglehold imposed by a worldview that was originally developed by the likes of John Locke, Adam Smith and Immanuel Kant during the period of European history rather questionably known as the Enlightenment. It is a major irony of this era of intense disputation and debate that, although the one principal issue upon which every one of its major luminaries appeared to agree was the need for their theories to have a firm foundation in science, the only significant body of scientific expertise that was actually available to them comprised the Newtonian laws of motion and mechanics. ${ }^{176}$ Needless to say, there are very severe limitations upon the level of understanding that can be attained with regard to the operations of human society and its relations with the natural world on the basis of analogies drawn from the circling of the planets and the collisions of billiard balls! While such a knowledge base, particularly when combined with the then nascent disciplines of chemistry and thermodynamics, proved an excellent springboard for launching the industrial and urban revolutions in human lifestyle, it had little or nothing of value to say about the preservation and cultivation of the natural resource base upon which all such developments must ultimately be posited. Indeed, such resources were widely asserted to be inexhaustible. ${ }^{177}$ Accordingly, luminaries such as Kant and Hume explicitly advocated the clearance of forests and the draining of marshes as a means of advancing human welfare and convenience. ${ }^{178}$ In Kant's mind, this was merely the

175 See generally Sands and Peel (n 57), chapters 18-21.

176 On the historical development of science, see, for example, G Johnson, Fire in the Mind (Penguin, 1995); E Mayr, This Is Biology (Belknap, Harvard UP, 1997), especially chapters 1-3; R Holmes, The Age of Wonder (Harper, 2008); Capra and Luisi (n 86). On the mechanistic worldview specifically, see, for example, DC Goodman and J Hedley Brooke (eds.), Towards a Mechanistic Philosophy (Open University Press, 1974).

177 See, for example, CJ Glacken, Traces on the Rhodian Shore (1967; p/b edn., University of California Press, 1992), chapter 14, discussing the views of Buffon, Montesquieu and other Enlightenment luminaries.

178 I Kant, Critique of Judgment (1790, 2nd edn., 1793; modern OUP edn., N Walker (ed.), 2007), part II, 1st Division, para 67; D Hume, 'Of the Populousness of Ancient Nations', 
application of those powers of rational deliberation which had liberated humankind from the constraints of natural causation!

The crucial problem here was that, even by the very end of the period in question, the most basic principles of biology were only just beginning to be formulated, while those of genetics, psychology, ecology and complex systems still remained effectively in the realms of terra incognita, if not terra improvisa. Eventually, moreover, even the one sure source of scientific guidance at the time, Newtonian physics, was to be exposed by the emergence of quantum theory as providing no more than the most rough-and-ready depiction of underlying reality. Accordingly, for all the undoubted intellectual genius from which they were spun, and the nuggets of genuine insight that they contained, far too many of the pronouncements of these luminaries rested on little more than personal preconception, tendentious speculation and recycled superstition. Even at the very summit of their sophistication, Enlightenment conceptions of human nature and relationship to the rest of the living world were far too primitive and preposterous to merit any serious measure of continued credence. Yet much of our contemporary thinking is still inclined to treat them as if they were unchallengeable truth. ${ }^{179}$ Indeed, it must surely be counted as the major intellectual tragedy of the 19th and 20th centuries that, as intellectual specialisation set in, disciplines such as philosophy and economics opted progressively to abandon the crucial Enlightenment injunction to ensure that all theorising remained continuously grounded upon the principles of natural science, while at the same time appearing to embrace wholeheartedly the crudely unenlightened 'junk' that was merely the product of its premature application. ${ }^{180}$ As a result, we have allowed ourselves to be seduced by a worldview that is altogether too simplistic, atomistic, mechanistic, materialistic, individualistic, humanistic, hubristic and, in the final analysis, wholly unrealistic. ${ }^{181}$

Yet, as vital as it is for the flourishing of the human species that this worldview be brought back into line with reality, it cannot plausibly be supposed that international wildlife lawyers in their capacity as such can be at the forefront of the revolution in thinking that is so urgently required. As concerned citizens, they should undoubtedly endeavour to ensure that their voices remain prominent in the escalating chorus for

included in Essays and Treatises on Several Subjects (Vol. 1, new edn., T. Cadell, 1793), $370-441,432$. This was a common attitude of the time.

179 For an extreme illustration of the corrosive effects of a traditional PPE education on the understanding of environmental issues, see N Lawson, An Appeal to Reason: A Cool Look at Global Warming (Duckworth Overlook, 2008).

180 Foremost amongst these sources of misdirection were the writings of commentators whose primitive conceptions of evolutionary theory and natural selection were deployed in order to substantiate their own ideological perspectives upon issues of politics, sociology and economics: note especially in this context W Bagehot, Physics and Politics (Batoche Books, 1872) and the prolific output of Herbert Spencer, who produced multi-volume treatments on a wide range of subjects, including biology, psychology, philosophy and sociology.

181 For a fascinating exposition of the psychological and neuro-scientific underpinnings of this imbalance, which is attributed to the unwelcome degree of supremacy that has emerged in our thinking on the part of the abstract and analytical processes of the left cerebral hemisphere over the more concrete, integrated and contextualising functions of the right, see I McGilchrist, The Master and His Emissary: The Divided Brain and the Making of the Western World (Yale UP, 2010). 
reform, but it is to the practitioners of the disciplines that lie at the heart of the problem that the world must principally look for change. ${ }^{182}$ With that in mind, it is encouraging to note that some of the most insistent demands for the transformation of economics are currently emanating from undergraduate students in that field, who not unnaturally feel entitled to expect that their studies should equip them with the kind of knowledge that might actually withstand scrutiny and application in the real world. ${ }^{183}$ Perhaps a similar openness to radical reform within the discipline of philosophy might do something to counter the depressingly low levels of current student interest in the subject.

Nevertheless, it would be naive in the extreme to suppose that it will be easy to expunge the pervasive imprints of this intellectual legacy from popular consciousness, not least because it appears to accord so closely with the semi-detached, suburban, self-indulgent consumerist lifestyles that already represent the ongoing reality for many of us, and the ardent aspiration for countless others. It may, however, be feasible to ensure that such a mindset comes at least to be balanced by one that reminds us that our apparent disjunction from the natural world is a mere illusion of short-term perspective, and thereby serves to bring us back down to (mother) earth. ${ }^{184}$ In particular, it will be salutary to be reminded that all the crucial ecological services and life support systems upon which our existence ultimately depends, including the very air that we breathe, do not represent an inevitable, natural outcome of the aggregation of matter into planetary form, but have been patiently assembled for us over time by the innumerable interactions of the diversity of life-forms that have chanced to emerge (perhaps uniquely in the universe) on one particular planet - ours. Furthermore, we disrupt the fundamental processes of this biosphere at our peril, since, however much we may flatter ourselves, the fleeting fads and fancies of arriviste decision-makers of our ilk may struggle to match the wisdom and rationality encapsulated in three-and-ahalf billion years of small-scale, highly distributed and continuously sustained trialand-error experiments in life support.

Nor would we seem well-advised to place our faith in those enduring but as yet inadequately substantiated Humanist assumptions regarding the unrelenting tendency towards progress in human affairs, ${ }^{185}$ since the historical record (the absolute entirety of which is in any event currently far too short in evolutionary terms to permit any

182 It is open to question whether even the more progressive elements within the discipline, who concede (p. 8) that nature 'has been ill-served by 20 th century economics', can display the flexibility and imagination needed to transform their discipline: see D Helm and C Hepburn (eds.), Nature in the Balance: The Economics of Biodiversity (OUP, 2014).

183 See Ha-Joon Chang and J Aldred, 'After the Crash, We Need A Revolution in the Way We Teach Economics' The Observer (London, 11 May 2014), which notes inter alia the launching of the International Student Initiative for Pluralism in Economics, now a collaboration of 65 student associations from 30 countries distributed across six continents, as to which see $<\mathrm{http} / / / \mathrm{www}$.isipe.net>. For a disappointingly (if predictably) muted account of these developments, see the Economist magazine (London, 7 February 2015), 27.

184 This is part of the purpose of the UN's Harmony with Nature project, as to which, see note 103 above.

185 For a sample of writings reflecting this way of thinking, see I Kramnick (ed.), The Portable Enlightenment Reader (Penguin, 1995), 351-395. 
meaningful conclusions in this regard) might actually be interpreted to demonstrate that apparent steps forward in one area of activity tend to be offset or even occasionally outflanked by regression in others. So here it is evident that humans in pre-industrial societies will have maintained a much clearer grasp of our relations with the natural world, for the simple reason that their everyday lives more directly and immediately depended upon it. Subsequently, however, our intuitive sense of such matters has been progressively eroded by the very nature of urban living, occupational specialisation and participation in the exchange economy - the very phenomena that Enlightenment scholars trumpeted as the engines of progress. Today, we must recognise that, for all the benefits they may have brought us, they have also caused us to lose sight of certain fundamental truths. Accordingly, if we are to retain any realistic prospect of fulfilling our aspirations for sustainable development, we will need not only to establish a viable vision to govern biodiversity conservation for the year 2020 and beyond, but also, as a crucial part of that process, somehow to contrive to restore or even improve upon our original capacity for 20:20 vision with respect to the workings of the world around us. ${ }^{186}$

Hopefully, this process is already under way, since the accumulated wisdom of the chthonic communities is explicitly recognised in the CBD as a resource which states should protect and draw upon, wherever appropriate, in their formulation and application of conservation policy. ${ }^{187}$ In that respect, it has the potential to serve variously as an inspiration, a supplement, a placeholder, a means of corroboration or even occasionally as a short-term corrective to the proceeds of more formal scientific endeavours, reference to which is also recurrent within the Convention. ${ }^{188}$ Through deployment of these twin sources of elucidation in the form of an epistemological pincer movement, ${ }^{189}$ it is hoped that the more ill-informed and environmentally destructive relics of Enlightenment thinking can progressively be expurgated, in the interests of the international community as a whole.

\subsection{Sharpening the Focus upon 'Community'}

This discussion should also serve incidentally as a reminder of the twin senses of the word 'community' itself, as highlighted in Section 3 above, and in particular of the virtues of the pluralism and diversity which is still to be found within our global society, and of the way in which it may be possible to draw upon it in circumstances

186 '20/20 vision is a term used to express normal visual acuity (the clarity or sharpness of vision) measured at a distance of 20 feet. If you have 20/20 vision, you can see clearly at 20 feet what should normally be seen at that distance. If you have 20/100 vision, it means that you must be as close as 20 feet to see what a person with normal vision can see at 100 feet': American Optometric Association, available at <http://www.aoa.org/>.

$187 \mathrm{CBD}$, Article 8(j) and 12th preambular recital.

188 Most obviously in the 7th preambular recital and then in Articles 12(a), 15-19 and 25, but reaffirmation of the relevance of science is actually pervasive throughout.

189 By a curious coincidence, an interesting example of precisely this combinatorial process was reported on the very day that this passage was drafted: see E Sohn, 'Inuit Wisdom and Polar Science Are Teaming Up to Save the Walrus', available via <http://www.smithsonianmag.com/>, and derived from 'What Now Walrus?', Hakai Magazine (Victoria, BC, Canada, 22 April 2015). 
where some broad uniformity of response must ultimately be adopted in response to the emergence of threats which are common to us all. Indeed, if there is anything to be identified as a guiding 'vision' for international wildlife lawyers, above and beyond the crucial need for them to 'stick resolutely to their legal last' in the analysis and evaluation of their subject-matter, and avoid the distractions generated by popular polemics, it might perhaps be found in the furtherance of understanding and practical realisation of the concept of community in all its various nuances. For a community in its most basic sense is, as suggested above, essentially no more than an aggregation of (potentially very disparate) entities interacting within a defined boundary. As a variety of complex living system, it is defined principally by simple reference to the fact that the exchange of energy within the encircling rampart is markedly more intense than that which occurs beyond it. The two things that will necessarily prove fatal to its capacity for self-maintenance are (i) if the barrier becomes totally impermeable to energy from without (for any closed system is doomed to the progressive dissipation and extinction of its internal order in accordance with the second law of thermodynamics) and (ii) that it should somehow lose the capacity to utilise this exogenous energy for the preservation of that internal order (in which case it will eventually disintegrate into and become indistinguishable from its surroundings in a functional sense). The biosphere itself represents a paradigm case here, because heterotrophs such as ourselves are entirely dependent upon the autotrophic life-forms to undertake the initial energy conversion (and starch creation) process which keeps us alive, ${ }^{190}$ while the service of recycling energy through the system is performed on our behalf by innumerable unheralded organisms from bats, bees and beetles to the microbes that permeate the soil. ${ }^{191}$ At the other end of the scale, apex predators and other keystone megafauna help to keep the whole system under overall operational control. ${ }^{192}$ It is therefore to the preservation and protection of community in its biological sense, and hence to the very possibility of community in any sense, that the work of wildlife law is ultimately directed.

It follows from this that no conservation regime can hope to be remotely effective unless it pays adequate regard to the principles of conservation science, and especially its holistic focus, and it is precisely that consideration that has led to the gradual transformation of wildlife law from an essentially species-oriented endeavour to one that concentrates much more broadly on entire ecosystems and the biological communities of which they are composed. Accordingly, the ecosystem approach has become critical to the implementation of the CBD itself and of the other treaties that

190 Autotrophs are organisms that can make their own food by synthesizing organic matter from inorganic substances, whereas heterotrophs can only derive their food from organic matter: Park (n 85), 36, 211.

191 It is for such reasons that one very recent opinion piece highlights midges, soil mites, dung beetles, fruit bats, ants, parrotfish and the cyanobacterium Prochlorococcus as the life-forms deserving of our most urgent attention: P Barkham, 'Which Would You Save?' BBC Wildlife magazine (Bristol, February 2015), 28, 35.

192 For an overview of the science, see C Fraser, 'The Crucial Role of Predators: A New Perspective on Ecology' Yale Environment 360 (New Haven, CT, 15 September 2011), available via <https://e360.yale.edu/>. 
operate within its broad sphere of influence. ${ }^{193}$ For the lawyer, the crucial questions therefore concern the extent to which treaty regimes are currently giving adequate attention both to the major threats that have been identified to the functioning and integrity of biological communities, and to the optimal forms of response that have been specified to address them.

\subsection{Maintaining Momentum: The Present Handbook}

It will therefore come as no surprise that a key function of the present work is to address such questions. In that vein, Arie Trouwborst analyses the extent to which treaty regimes are successfully addressing the problem of habitat fragmentation, while Peter Davies investigates, through the prism of the EU regime, the ubiquitous problems posed by alien invasive species. The incidence of armed conflict represents another recurrent threat to wildlife, and this is examined in the chapter by Karen Hulme. The conservation of vulnerable marine ecosystems is considered by Edward Goodwin, while Rosemary Rayfuse also examines the marine environment, but specifically in the light of the hazards posed by climate change, not only in the form of global warming, but through the process of ocean acidification. With a particular emphasis on response strategies, Kees Bastmeijer considers the extent to which the managed restoration of ecosystems and their essential functioning processes represents a feasible solution or palliative to past failures to prevent harm.

In addition to illuminating the substantive conservation principles by which wildlife treaty regimes are informed, these chapters shed incidental light upon the institutions and procedures through which they are operationalised, and this issue of course represents a crucial focus of study in its own right. It should be noted that the discipline of international environmental law has made a very significant contribution to the development of the international legal system generally, through its exploration of the various ways in which the treaty instrument can be reconceived and elaborated in order to maximise its potential impact. In particular, the investment of treaty regimes with elaborate institutional arrangements of a dedicated, quasi-autonomous kind has helped to transform the 'sleeping treaties' - or perhaps, to adopt an alternative analogy, abiotic mechanisms - of the past into the familiar 'living instruments' of the modern era. ${ }^{194}$ These biological metaphors are employed advisedly, for contemporary conservation regimes are organic in more than a purely figurative sense, by virtue of their creation of a specialised form of political community for the achievement of their objectives. Furthermore, it can be argued that the strength of any system of this kind is likely to depend considerably upon the extent to which it successfully replicates the essential features of a natural ecosystem. ${ }^{195}$ Indeed, a political community, as noted above, is

193 For an explanation, see <https://www.cbd.int/ecosystem/>.

194 RR Churchill and G Ulfstein, 'Autonomous Institutional Arrangements in Multilateral Environmental Agreements: A Little-Noticed Phenomenon in International Law' (2000) 94 AJIL 623.

195 See MJ Bowman, "Beyond the "Keystone" CoPs: The Ecology of Institutional Governance in Conservation Treaty Regimes' (2013) 15 International Community Law Review 5-43 
itself merely a variety of complex living system, and the plant geneticist Enrico Coen has recently argued that the same handful of basic principles in fact govern the functioning of all such entities, from individual living cells to entire human civilisations. ${ }^{196}$

Given the importance of diversity as a source of strength, of critical importance to the maximisation of the potential of treaties is the question of participation, and especially its extension beyond the sphere of statehood. This question must therefore be kept under continuous scrutiny, and for the purposes of this work Elizabeth Kirk examines specifically the role of non-state actors in certain marine biodiversity treaty regimes. Needless to say, the litmus test of the effectiveness of treaty institutions in this context will be seen by many as relating to the extent to which they prove successful in holding states to their commitments. Karen Scott's contribution is accordingly devoted to the investigation of the various procedures that have been adopted under wildlife treaties to date to address the crucial issue of non-compliance. One of the many interesting points to emerge from this study is the increasing occurrence of joint ventures by treaty bureaucracies in the implementation of such procedures, which serves as a reminder that such regimes operate not in splendid (or, perhaps one should say, wretched) isolation, but as part of a broader network or community of biodiversityrelated Conventions. It would seem a reasonable aspiration that these regimes should not in any way compromise or undermine each other's work, and wherever possible seek synergies and opportunities for collaboration. The focus of Richard Caddell's chapter is therefore upon the extent to which such aspirations have so far been realised in practice, and the prospects for further instances of mutual reinforcement in the future.

This chapter also serves to confirm a point which is evident from certain other contributions already mentioned above, namely that many communities, whether of a normative or other character, commonly find themselves nested, after the fashion of Russian dolls, within broader systems or forms of polity. Thus, the network of biodiversity-related treaties to which Caddell refers can itself be located within a wider field of instruments devoted to environmental protection (as instanced by the interface between biodiversity and climate change, discussed by Rayfuse), and in turn within the still broader domain of international law generally (as exemplified in this work by the interaction of conservation norms with the regime governing armed conflict, explored by Hulme). As the perspective progressively widens in this way, the challenge of maintaining an appropriate degree of normative coherence tends to intensify, a point which is demonstrated very graphically in the chapter by Emilie Cloatre. This concerns the possibility of successfully reconciling - or at least reaching some form of workable accommodation between - the sharply contrasting regulatory demands of commerce and industrial property on the one hand and anthropology and human rights on the other in relation to the exploitation of biological resources. Since it is in the

and M Fitzmaurice and D French (eds.), International Environmental Law and Governance (Brill/Nijhoff, 2015).

196 These are population variation, persistence, reinforcement, competition, cooperation, combinatorial richness and recurrence: for elaboration, see E Coen, Cells to Civilizations: The Principles of Change that Shape Life (Princeton UP, 2012). 
conservation forum that these contrasting perspectives have chanced to meet head on, the question arises as to whether the CBD represents an appropriate crucible to achieve a viable amalgam, or whether some other venue or approach might be needed for this purpose. It should also be apparent that the tension here arises from the clash of two very different cultural communities and epistemic traditions; one is derived from the Enlightenment injunction to subjugate, control and assert ownership over the natural world, and the other from a long pre-existing and hopefully still active disposition to submit to the rhythms of its regenerative process and thereby be prepared, at least to some extent, to dance to its chosen tunes. On this view, membership rather than ownership, and harmony rather than hegemony, may have to be the vital watchwords for our relationship with nature in the future. A viable legal solution to the problems regarding intellectual property is only likely to emerge from practice, but it should come as no surprise that this practice might itself entail a very great deal of trial and error.

Certainly no single faction or interest group should feel entitled to assume that its own preferences or proclivities will automatically prevail in this regard, but the fact that conservation has been conclusively declared to represent the common concern of all humankind should at least give every relevant constituency a measure of standing in the matter. Even the hallowed, and strongly reaffirmed, ${ }^{197}$ sovereignty of states over their living natural resources must now be exercised in conformity with the normative ethos of the CBD and other relevant instruments. Undeniably, the precise nature and implications of the common concern idea are not entirely pellucid, and Duncan French duly takes the opportunity in his chapter to offer further elaboration of the way in which the concept is currently evolving. Plainly, the attribution of this status stems from the acknowledged importance of biodiversity for the pursuit of sustainable development, which has become one of the defining objectives of the international community as a whole. Yet this idea too, for all the attention that it has commanded from commentators, remains open to ongoing interpretation and exegesis, and Veit Koester accordingly takes on the task of examining the extent to which it has been respected and applied in the practice of the Biodiversity Convention itself. What cannot be denied is that a commitment to equity, in both its inter- and intra-generational dimensions, represents a key component, and it is this issue which forms the focus of the chapter by Malgosia Fitzmaurice, as reflected in the ongoing controversies played out in the IWC, the constituent instrument of which was one of the first to contain explicit reference to such matters.

Each one of these fundamental principles of international environmental law would seem to place a premium on the question of participation, since it has become widely accepted that the dictates of good governance demand that all those who form part of a political community should have some role to play in the elaboration of the normative processes by which they are regulated. As noted above, the issue is tackled directly in relation to marine biodiversity treaty regimes in the chapter by Kirk, and also represents a pervasive theme of Cloatre's contribution insofar as it impacts upon indigenous communities and other traditional users of biological resources. The elucidation of this topic is enriched still further by Nicole Mohammed's instructive case

197 See especially CBD, Article 3. 
study of participatory resource management in the Caribbean, which suggests that there are very considerable problems to be overcome in order to make the aspiration of public participation a meaningful reality.

The significant practical problems associated with public participation produce the inevitable result, in many contexts, that it has to be realised in representative mode rather than personally. ${ }^{198}$ That being so, it is relevant to ask whether there might be claims or interests that merit representation in appropriate forums and procedures regardless of the fact that the entities to which they relate could never be envisaged as direct participants in their own right and on their own behalf. To put it another way, many - indeed, the vast majority - of those who hold stakes in the ultimate success of our conservation endeavours are not human at all, raising the question of whether and how their interests are to be taken into account. At root, of course, this is a matter of values, and whether only those of an exclusively anthropocentric orientation are worthy and capable of accommodation. This key question is revisited in the chapter which immediately follows the present one, in which Mattia Fosci and Tom West conclude that it would be preferable to pursue policies that aim to be compatible with both intrinsic and instrumental modes of valuation than to continue to argue about their relative importance.

\subsection{Final Reflections}

This preference for pluralism seems very much in line with the conclusions that have begun to emerge from reflections on the financial crash and other policy disasters of recent years. As one leading financial expert puts it:199

If you are clear about your high-level goals and knowledgeable enough about the systems their achievement depends on, then you can solve problems in a direct way. But goals are often vague, interactions unpredictable, complexity extensive, problem descriptions incomplete, the environment uncertain. That is where obliquity comes into play.

Where conservation is concerned, the ultimate truth is probably that even if we were disposed to be utterly selfish, we simply do not know enough to determine which elements of the natural world are critical to our own survival or success and which we can safely allow to go to the wall. The one thing of which we can be sure is that we are all part of the same global biotic community, and whereas a community of this kind does not necessarily involve much in the way of commonality, it does invariably involve highly complex networks of interdependence. It was considerations such as these that caused Aldo Leopold to conclude long ago that 'a thing is right when it tends to preserve the integrity, stability and beauty of the biotic community. It is wrong when it tends otherwise.' ${ }^{200}$ In consequence, we shall probably arrive ultimately at the same

198 To take an obvious example, the rules governing participation in CoP meetings - as to which see notes 194-195 and accompanying text - tend to focus upon 'bodies' or 'agencies' rather than individuals.

199 J Kay, Obliquity: Why Our Goals Are Best Achieved Indirectly (Profile Books, 2010), 178.

200 A Leopold, A Sand County Almanac (1949, Ballantine Books reprint 1986), 224-225. 
broad policy conclusions regardless of whether we resolve initially to set off along the road of prudential self-interest or that of expansive ethical altruism: as the 1991 revised version of the World Conservation Strategy made clear, respect and care for the community of life represents the underlying ethic that provides the foundation for all the other principles on which sustainable living depends. ${ }^{201}$

Although we cannot easily calculate what level of investment in conservation is likely to be needed for this purpose, we should probably bank on it being considerably more than we have hitherto imagined we could possibly afford. ${ }^{202}$ This realisation helps, indeed, to explain why it is difficult to understand how an unreformed discipline of economics can ever play more than an important supporting role in the determination of policy priorities: by systematically disenfranchising all those beings who do not participate in the exchange economy, it merely serves to perpetuate the manifold and intractable problems that have been caused by the commodification of nature in the first place. Perhaps, then, its only real hope for redemption would lie in the recognition of historic property rights over natural ecosystems on the part of all those species that have traditionally inhabited them, and asking them (or more plausibly some trustee acting on their behalf) how much they would be prepared to accept by way of compensation for any projected loss or despoliation of their habitat!

Since such an intellectual revolution might well take some considerable time to deliver, it would be preferable for the practitioners of other disciplines not simply to wait for it to happen, but rather to attempt in the meantime to make some more immediate progress of their own in the same general direction. For lawyers, this might entail exploring the various ways that might be found for giving a voice (if only through surrogates) to those countless stakeholders in the conservation process who, in the very nature of things, are constitutionally disabled from participation in verbal deliberation - that is to say, all those not of our own particular (sub-)species. If this should seem outlandish, it is to be remembered that the proposal already finds reflection in current arrangements to some extent through the admission to meetings of many treaty bodies of certain non-governmental entities 'technically qualified in protection, conservation or management of wild flora and fauna'. ${ }^{203}$ Bodies with a proven record of positive contribution may in some cases see this recognised through the formal grant of 'partnership' status, which typically offers enhanced opportunities for participation. If there are treaties which deny or unduly hamper such engagement on the part of civil society, their practices might profitably be reconsidered. ${ }^{204}$

201 IUCN/UNEP/WWF, Caring for the Earth: A Strategy for Sustainable Living (IUCN, 1991), see especially chapters 1 and 2. See further the chapter by Fosci and West in this volume.

202 To set things in context, the total value of the ecosystem services provided for us by nature each year has been estimated to be worth around double global GDP: A Juniper, What Has Nature Ever Done for Us? How Money Really Does Grow on Trees (Profile Books, 2013).

203 As per CITES, Article 11(7), for example.

204 Fisheries treaties might seem to be a case in point: for discussion, see GM Wiser, 'Transparency in 21st Century Fisheries Management: Options for Public Participation to Enhance Conservation and Management of International Fish Stocks', a revised version of a WWF paper presented to a major fisheries conference in 2000, available via <http:// www.ciel.org/Publications/trans21cenfisheries_options.pdf>; also D Symes, 'Fisheries Governance: A Coming of Age for Fisheries Social Science' (2006) 81 Fisheries Research 113-117. 
Yet this approach does not of itself guarantee representivity of the kind envisaged, for it is not normally a requirement that such groups serve specifically as advocates for nature's interests: many doubtless do, but others may not at all, especially where their qualification for entry is derived, say, from the function of 'management' rather than 'protection'. ${ }^{205}$ Consequently, there is scope for the exploration of other possibilities, especially since most of these are unlikely to be mutually exclusive. It should not be assumed, moreover, that states themselves have no part to play in this process, and it may indeed be worthwhile to explore further the process of designating particular states as 'champions' for certain species akin to that dabbled with by the Bonn Convention in connection with its 'concerted actions' procedure. ${ }^{206}$ Perhaps other comparable avenues will come to light from a detailed exploration of practice under wildlife treaties generally - and if this is now to be described as making 'interstitial headway', then so be it.

A further point to note is that the route to more effective representation of nature's interests should certainly not be confined to the sphere of activities conducted under the aegis of existing conservation treaty institutions, as there may be scope for the utilisation also of judicial process for this purpose, whether at the national, regional or international level. Some examples have already been encountered earlier in this chapter, and it is for wildlife law researchers to ensure that there is a sufficient body of serious literature available to provide potential litigators with an adequate array of weapons for their forensic armoury. In addition to already familiar forms of legal action, the potential of new approaches should no doubt also be explored. There could hardly be a more auspicious moment than now, for while it was predictable that attempts to utilise the procedures of the European Convention on Human Rights for the benefit of hominids beyond our own species would be summarily rebuffed, ${ }^{207}$ it cannot pass unremarked that various media sources have reported, though perhaps prematurely, a writ of habeas corpus being granted in national law for the benefit of just such an unconventional applicant - to wit, an orang-utang in the courts of Argentina, following an earlier case concerning a chimpanzee in Brazil, where the judge declined to rule out the possibility in limine. ${ }^{208}$ While these cases obviously concern captive animals, seen purely as individuals, any such breaches in the barrier of legal personhood may conceivably carry implications in the longer term for their counterparts in the wild as well, and on a collective basis. Indeed, it is noteworthy that there is already one wildlife treaty, the 2007 Agreement for the Conservation of Gorillas and Their Habitats, ${ }^{209}$ which appears to place unusually high emphasis upon the moral status and substantive interests of gorillas when set alongside that of their close relatives, our own

205 Both activities are mentioned, alongside conservation, as relevant forms of expertise for the purposes of CITES, for example; see Article 11(7).

206 For discussion, see Lyster, 574-576.

207 ECHR admissibility decisions are no longer routinely published, but the cases in question are discussed by Judge Pinto de Albuquerque in his partly concurring/partly dissenting opinion in the recent case of Herrmann v Germany, Application No. 9300/07, Grand Chamber Judgment of 26 June 2012: see in particular footnote 22 and accompanying text.

208 For information on such developments generally, see <http://www.nonhumanrights project.org $>$.

209 Text available via <http://www.cms.int/gorilla/en/documents/agreement-text $>$. 
species.210 It does not go so far as to recognise formal legal rights on their part, however, and it remains uncertain whether any such development in international law could offer a viable route towards progress in the field of conservation. Nevertheless, the issue certainly seems worthy of further consideration and research. ${ }^{211}$

This suggests that the time may well have come when Christopher Stone's memorable question, 'Should Trees Have Standing?' must receive more active and systematic attention. ${ }^{212}$ Certainly, the 2012 Rio+20 Conference on Sustainable Development not only reaffirmed the need for promoting 'harmony' with nature but went on to acknowledge that some countries already recognise the rights of nature in this context. $^{213}$ This recognition may sometimes, perhaps, be essentially of a purely rhetorical character, but recent developments suggest that some states have been prepared to go further: thus, the website which the UN has dedicated to the Harmony with Nature project makes reference to what is presented as the first victory and explicit vindication of the rights of nature in a national court: a case in 2011 concerning the River Vilcabamba in Loja province, Ecuador. ${ }^{214}$ There is, moreover, other evidence that such ideas are now beginning to acquire a degree of traction in the legal realm. ${ }^{215}$

Finally, and back outside the courtroom, consideration could profitably be given to the creation of entirely new types of legal forum or institution, despite the alleged waning of enthusiasm amongst governments for initiatives of this kind. It is noteworthy that the coming to a close of the Decade for Biodiversity will coincide almost exactly with the centenary of the emergence onto the global stage of an institution that was entirely revolutionary for its time: the International Labour Organization. ${ }^{216}$ At a time when international law was resolutely statist in orientation, and well before the formal consolidation of human rights into the system, the creation of a body in which a

210 Note in particular Article III(2)(a), (j).

211 For an excellent foundation, though without any particular focus on international law, see CR Sunstein and MC Nussbaum (eds.), Animal Rights: Current Debates and New Directions (OUP, 2004).

212 His article of that name was sub-titled 'Toward Legal Rights for Natural Objects' and published in (1972) 45 Southern California Law Review 450. See also his book of the same title, published by Oxford University Press (3rd edn., 2010).

213 See the outcome document The Future We Want (2012), and especially paragraph 39, available via $<$ http://www.un.org/en/sustainablefuture/>.

214 A report (in Spanish) is available via <http://www.harmonywithnatureun.org/rights ofnature.html>. For a summary in English, with accompanying commentary, see N Greene, 'The First Successful Case of the Rights of Nature Implementation in Ecuador', available at $<$ http://therightsofnature.org/first-ron-case-ecuador $>$.

215 Note in particular the 2012 Wanganui River Treaty, a framework agreement between the Crown and certain indigenous communities in New Zealand, which recognises the river as a living entity in its own right, incapable of being 'owned' in an absolute sense and enjoying legal standing of its own. The text may be viewed at http://www.harmonywithnatureun.org/content/ documents/193WanganuiRiver Agreement-.pdf.

216 The ILO was created pursuant to Part 13 of the 1919 Treaty of Peace with Germany, 225 CTS 188. For its website, see <http:www.ilo.org/>, and for discussion of its activities see, for example, S Hughes and N Haworth, The International Labour Organization (ILO): Coming in from the Cold (Routledge, 2011); JM Servais, International Labour Organization (ILO) (Kluwer Law International, 2011); F Maupain, The Future of the International Labour Organization in the Global Economy (Hart Publishing, 2013). 


\section{2}

tripartite structure was created to give an equal voice to workers and employers alongside that of governments must surely be counted as one of the most imaginative of all developments within the global legal order. Perhaps there is now scope for a similar expansion of consideration to those who currently stand outside the pale of legal personhood.

Yet whatever the need for investigating such radical initiatives, it seems clear that wildlife lawyers should not allow themselves to become too carried away in their pursuit. The bulk of the research agenda, as reflected in the contributions to this work, should continue to be devoted to more mainstream issues, focusing on the tweaking of existing systems designed to secure measurable, if usually small-scale, improvements in the delivery of their fundamental objectives. Whatever the precise orientation of their efforts, moreover, researchers should prepare themselves for the dispiriting possibility that their labours may seem to have regrettably little discernible impact in practice, or even to go entirely unheeded. Hopefully, however, all such work will contribute in some way to the overall drip-feed of pressure by which governments and other key decision-makers are over the course of time imperceptibly affected. After all, the quantity of oxygen produced by a single cyanobacterium is doubtless infinitesimally small, but collectively they have created the essential conditions under which all the more complex life-forms, including ourselves, could develop.

So, too, in the sphere of international environmental governance, the chorus of pressure emerging from various disciplines has already produced some highly significant and promising developments during the Decade for Biodiversity. And if it should sometimes seem discouraging that more dramatic progress is so difficult to come by in this context, wildlife lawyers will simply have to find ways of stiffening their resolve, using whatever form of metaphorical starch might come to hand; perhaps it will help to be reminded that their collective efforts are devoted to securing the processes by which the literal version of this complex chemical is generated, and hence to preserving the very staff of life itself, not only for themselves, but for their children and their children's children.

If, on the other hand, the need is felt for some more tangible form of incentive and inspiration to motivate endeavours in this field, it always pays to remember that there are certainly plenty of individual conservation success stories to hold on to among the standard tales of doom and gloom. ${ }^{217}$ Here is one that holds particular significance for me.

From my schooldays in the 1960s, I recall the graphic accounts in the media regarding the collapse of peregrine falcon numbers in the UK and elsewhere, as the calamitous effect of pesticides upon their breeding success served to exacerbate the more traditional threats posed to them by habitat encroachment and direct human persecution. ${ }^{218}$ Indeed, their decline seemed almost as precipitate as the spectacular

217 For a valuable selection of examples, see the FFI publications Fauna \& Flora, Issue 18, December 2013 and its special supplement, 'Many Happy Returns from the Brink: Celebrating Fauna and Flora International's 110th Anniversary' and Fauna and Flora International Update No. 27, September 2015.

218 JJ Hickey (ed.), Peregrine Falcon Populations: Their Biology and Decline (University of Wisconsin Press, 1969); DA Ratcliffe, The Peregrine Falcon (T and AD Poyser, 1980). 
aerial 'stoops' by which they hurtle down on their unsuspecting prey. I knew little about such matters at the time, but, growing up in the London area, it was difficult to understand how such seemingly exotic creatures could possibly survive at all in a country that was so heavily urbanised and industrialised, whatever protective measures might be put in place.

Twenty years later, when I was established in a career as a university lecturer and contemplating the introduction of wildlife conservation into the Nottingham legal curriculum for the first time, I heard of the recolonisation by a pair of peregrines of one of their traditional breeding sites at Symonds Yat, a rocky outcrop along the River Wye, on the Gloucestershire/Herefordshire border. The Royal Society for the Protection of Birds had established a wardenship scheme and a public viewpoint across the river in the hope of garnering popular support for their attempts to translate formal protective legislation for this species into practical conservation success. Like thousands of others, I went to see these magnificent birds, though without really knowing whether their reappearance at this site signalled a genuine recovery in numbers, or was merely a last, defiant gesture in the death throes of the species in Britain. Whatever the truth of that particular saga, wildlife law duly secured a foothold in the curriculum, initially as part of a single, optional course in international environmental law designed to serve our new LLM degree in international law.

Now, a further 30 years on, the international law of biodiversity seems well entrenched here, with 50 undergraduate subscribers this session and a regular cohort of postgraduate students, some of whom devote their entire masters programme to the study of environmental law. And should you be more concerned (as I hope you will be) about the actual targets of all this academic attention, it may interest you to note that, as I left the building after the first seminar of the 2015-2016 session, a peregrine falcon could be seen hunting from the clock tower almost immediately above the room in which the class had taken place: so successful, indeed, has been the recovery programme for the species globally that their conservation status is now categorised as 'Least Concern' by IUCN. Iconic, once gravely imperilled, raptors silhouetted against the evening sky, apparently flourishing on the fringes of a major conurbation set in the heart of the English industrial midlands 219 - now that is a 'vision' worth holding on to!

\section{SELECT BIBLIOGRAPHY}

Bowman, MJ, PGG Davies and CJ Redgwell, Lyster's International Wildlife Law (2nd edn., CUP, 2010)

Capra, F and PL Luisi, The Systems View of Life: A Unifying Vision (CUP, 2014)

Cullinan, C, Wild Law (Siber Ink, 2002)

Fitzmaurice, M and D French (eds.), International Environmental Law and Governance (Brill/Nijhoff, 2015)

Gillespie, A, Conservation, Biodiversity and International Law (Edward Elgar Publishing, 2013)

Gillespie, A, International Environmental Law, Policy and Ethics (2nd edn., OUP, 2014)

Harmony with Nature, Report of the UN Secretary-General, UN Doc A/69/322, 18 August 2014

Helm, D and C Hepburn (eds.), Nature in the Balance: The Economics of Biodiversity (OUP, 2014)

219 Indeed, peregrines have actually established nesting sites right in the very centre both of Nottingham and of neighbouring Derby, as can be observed over the internet through webcam arrangements serving each. 


\section{Research handbook on biodiversity and law}

Kay, J, Obliquity: Why Our Goals Are Best Achieved Indirectly (Profile Books, 2010)

Mathews, F, The Ecological Self (Routledge, 1991)

McGilchrist, I, The Master and His Emissary: The Divided Brain and the Making of the Western World (Yale UP, 2012)

Mepham, B, Bioethics: An Introduction for the Biosciences (2nd edn., OUP, 2008)

Nussbaum, MC, Frontiers of Justice (Belknap, Harvard, 2006)

Wandesforde-Smith, G, 'From Sleeping Treaties to the Giddy Insomnia of Global Governance: How International Wildlife Law Makes Headway' (2012) 15 JIWLP 80 